\title{
RNA interference as a gene silencing tool to control Tuta absoluta in tomato (Solanum lycopersicum)
}

\author{
Roberto A Camargo ${ }^{1,2}$ ， Guilherme O Barbosa ${ }^{3}$ ， Isabella Presotto Possignolo ${ }^{1,2}$ ， Lazaro E. P. Peres ${ }^{2}$, Eric Lam \\ 4, Joni E Lima ${ }^{5}$, Antonio Figueira ${ }^{\text {Corresp., }}{ }^{1}$, Henrique Marques-Souza ${ }^{\text {Corresp. } 3}$ \\ ${ }^{1}$ Centro de Energia Nuclear na Agricultura, Universidade de São Paulo, Piracicaba, São Paulo, Brazil \\ 2 Escola Superior de Agricultura “Luiz de Queiroz" (ESALQ), Universidade de São Paulo, Piracicaba, São Paulo, Brazil \\ 3 Departamento de Bioquímica e Biologia Tecidual, Universidade Estadual de Campinas, Campinas, São Paulo, Brazil \\ 4 Department of Plant Biology \& Pathology, Rutgers, The State University of New Jersey, New Brunswick, New Jersey, United States \\ 5 Departamento de Botânica, Universidade Federal de Minas Gerais, Belo Horizonte, Minas Gerais, Brazil \\ Corresponding Authors: Antonio Figueira, Henrique Marques-Souza \\ Email address: figueira@cena.usp.br, hmsouza@g.unicamp.br
}

RNA interference (RNAi), a gene-silencing mechanism that involves providing doublestranded RNA molecules that match a specific target gene sequence, is now widely used in functional genetic studies. The potential application of RNAi-mediated control of agricultural insect pests has rapidly become evident. The production of transgenic plants expressing dsRNA molecules that target essential insect genes could provide a means of specific gene silencing in larvae that feed on these plants, resulting in larval phenotypes that range from loss of appetite to death. In this report, we show that the tomato leafminer (Tuta absoluta), a major threat to commercial tomato production, can be targeted by RNAi. We selected two target genes [Vacuolar ATPase-A and Arginine kinase] based on the RNAi response reported for these genes in other pest species. In view of the lack of an artificial diet for T. absoluta, we used two approaches to deliver dsRNA into tomato leaflets. The first approach was based on the uptake of dsRNA by leaflets and the second was based on "in planta-induced transient gene silencing" (PITGS), a well-established method for silencing plant genes, used here for the first time to deliver in planta-transcribed dsRNA to target insect genes. Tuta absoluta larvae that fed on leaves containing dsRNA of the target genes showed an $\sim 60 \%$ reduction in target gene transcript accumulation, an increase in larval mortality and less leaf damage. We then generated transgenic 'Micro-Tom' tomato plants that expressed hairpin sequences for both genes and observed a reduction in foliar damage by $\mathrm{T}$. absoluta in these plants. Our results demonstrate the feasibility of RNAi as an alternative method for controlling this critical tomato pest. 
1 RNA interference as a gene silencing tool to control Tuta absoluta in tomato (Solanum lycopersicum)

2 Roberto de A. Camargo ${ }^{1,2}$, Guilherme O. Barbosa ${ }^{3}$, Isabella Possignolo ${ }^{1,2}$, Lazaro E. P. Peres ${ }^{2}$, Eric Lam ${ }^{4}$,

3 Joni E. Lima ${ }^{5}$, Antonio Figueira ${ }^{1^{*}}$, Henrique Marques-Souza ${ }^{3^{*}}$

$4 \quad{ }^{1}$ Centro de Energia Nuclear na Agricultura, Universidade de São Paulo, Piracicaba, São Paulo, Brazil;

5 Escola Superior de Agricultura “Luiz de Queiroz” (ESALQ), Universidade de São Paulo, Piracicaba, São

6 Paulo, Brazil;

$7 \quad{ }^{3}$ Departamento de Bioquímica e Biologia Tecidual, Universidade Estadual de Campinas, Campinas, São

8 Paulo, Brazil;

$9 \quad{ }^{4}$ Department of Plant Biology \& Pathology, Rutgers, The State University of New Jersey, New Brunswick,

10 New Jersey, United States.

11 Departamento de Botânica, Universidade Federal de Minas Gerais, Belo Horizonte, Minas Gerais, Brazil;

$12{ }^{*}$ Corresponding authors

13 *Antonio Figueira - figueira@cena.usp.br

14 *Henrique Marques-Souza - hmsouza@unicamp.br 


\section{Abstract}

16 RNA interference (RNAi), a gene-silencing mechanism that involves providing double-stranded RNA

17 (dsRNA) molecules that match a specific target gene sequence, is now widely used in functional genetic

18 studies. The potential application of RNAi-mediated control of agricultural insect pests has rapidly

19 become evident. The production of transgenic plants expressing dsRNA molecules that target essential

20 insect genes could provide a means of specific gene silencing in larvae that feed on these plants, resulting

21 in larval phenotypes that range from loss of appetite to death. In this report, we show that the tomato

22 leafminer (Tuta absoluta), a major threat to commercial tomato production, can be targeted by RNAi. We

23 selected two target genes [Vacuolar ATPase-A and Arginine kinase] based on the RNAi response reported

24 for these genes in other pest species. In view of the lack of an artificial diet for T. absoluta, we used two

25 approaches to deliver dsRNA into tomato leaflets. The first approach was based on the uptake of dsRNA

26 by leaflets and the second was based on "in planta-induced transient gene silencing” (PITGS), a well-

27 established method for silencing plant genes, used here for the first time to deliver in planta-transcribed

28 dsRNA to target insect genes. Tuta absoluta larvae that fed on leaves containing dsRNA of the target

29 genes showed an $\sim 60 \%$ reduction in target gene transcript accumulation, an increase in larval mortality

30 and less leaf damage. We then generated transgenic 'Micro-Tom' tomato plants that expressed hairpin

31 sequences for both genes and observed a reduction in foliar damage by T. absoluta in these plants. Our

32 results demonstrate the feasibility of RNAi as an alternative method for controlling this critical tomato

33 pest. 


\section{Introduction}

The mechanism of RNA interference (RNAi), in which small RNAs can rapidly cause posttranscriptional specific gene silencing, has become a powerful tool for analysing gene function in a variety of organisms (Hannon, 2002). The mediators of sequence-specific mRNA degradation are 21 nucleotidelong short-interfering RNA molecules (siRNA) generated from Dicer cleavage of longer double-stranded RNA (dsRNA) (Zamore et al., 2000). Gene silencing by introducing dsRNA into organisms has proven to be an excellent strategy for reducing specific gene expression in several insect orders, including Diptera, Coleoptera, Hymenoptera, Orthoptera, Blattodea, Lepidoptera and Isoptera (Katoch et al., 2013). The potential application of RNAi-mediated control of agricultural insect pests has rapidly become evident (Gordon \& Waterhouse, 2007), but a major challenge has been the development of an easy, reliable method for dsRNA production and delivery. The original RNAi studies used microinjection to deliver dsRNA into insects; 'soaking' has also been used as a delivery method to target cell cultures or individual larvae (Price \& Gatehouse, 2008). The demonstration that dsRNA uptake through ingestion was sufficient to reduce target gene expression allowed the possibility of applying RNAi on a larger scale (Koch \& Kogel, 2014). Transgenic plants engineered to express insect dsRNAs emerged as a potential technology after two independent groups proved the concept of applying RNAi to control agricultural insect pests (Baum et al., 2007; Mao et al., 2007). This approach has been developed to control lepidopteran, coleopteran and hemipteran agricultural pests (Katoch et al., 2013; Li et al., 2012; Paim et al., 2013), including Helicoverpa armigera in cotton (Mao et al., 2011; Mao et al., 2015; Qi et al., 2015; Chikate et al., 2016) and tobacco (Zhu et al., 2012; Xiong et al., 2013; Tian et al., 2015; Mamta et al., 2016), Diabrotica virgifera virgifera in maize (Baum et al., 2007; Fishilevich et al., 2016), Nilaparvata lugens in rice (Zha et al., 2011; Li et al., 2011; Yu et al., 2014; Qiu et al., 2016), Myzus persicae (Mao \& Zeng, 2014; Tzin et al., 2015) in Nicotiana benthamiana (Khan et al., 2013; Pitino et al., 2011) and Arabidopsis thaliana (Coleman et al., 2014; Li et al., 2015) and Sitobion avenae in wheat (Xu et al., 2014). However, the availability of methods that allow the screening and evaluation of candidate RNAi targets is a critical requisite for developing specific and efficient RNAi-based pest control. 

that attacks many solanacean species, particularly Solanum lycopersicum (tomato) and other species of economic importance (Cifuentes et al., 2011; Desneux et al., 2010). The tomato leafminer is a multivoltine species whose young larvae can damage tomato plants during all developmental stages by forming large galleries in the leaves and burrowing into stalks, shoot apex, and green and ripe fruits. Tuta absoluta, which can cause yield losses of up to $100 \%$ in various regions and under diverse cultivation systems, has become the major tomato pest in South America and Africa (Desneux et al., 2010; Urbaneja et al., 2013; Campos et al., 2014; Tonnang et al., 2015). This insect invaded Europe in 2006 and spread to northern Africa in 2007 (Urbaneja et al., 2013), where it caused extensive economic losses to growers; multiple efforts have since been made to control this pest (Desneux et al., 2011). To aggravate this situation, resistance to insecticides has been reported for T. absoluta, making the development of alternative means of controlling this pest even more urgent (Urbaneja et al., 2013; Campos et al., 2014; Silva et al., 2015).

To provide an alternative method of control based on RNAi we first investigated two approaches for delivering dsRNA to T. absoluta larvae, a critical requisite for efficiently screening effective target genes before developing transgenic plants. Traditionally, target genes are screened and evaluated by adding dsRNA to artificial diets offered to insect larvae (Terenius et al., 2011; Zhang, Li \& Miao, 2012; Wang et al., 2015; Fishilevich et al., 2016), but in the case of T. absoluta, there is no readily available artificial diet (Urbaneja et al., 2013). We therefore investigated two delivery approaches in which $T$. absoluta larvae feed on tomato leaflets containing dsRNA. In the first approach, tomato leaflets were allowed to uptake dsRNA from an aqueous solution, in a manner similar to that described for the sapsucking Bemisia tabaci (Luan et al., 2013). The second approach was based on the transient transcription of dsRNA by the host plant after the infiltration of Agrobacterium cells carrying binary plasmids that expressed hairpin versions of the target gene sequences ('agro-infiltration'). Agro-infiltration was originally developed to investigate plant-virus interactions (Bendahmane et al., 2000) but was later adapted to functional analyses of plant genes, e.g., for assessing gene over-expression or silencing and 
87 silencing constructs in wheat to determine the pathogenicity-related gene functions of Puccinina triticina

88 (leaf rust) (Panwar et al., 2012). Here, we investigated whether the same rationale could be used to silence 89 insect genes.

90 The target genes selected for this study were the Vacuolar ATPase catalytic subunit A gene (V91 ATPase) and Arginine kinase (AK). The $\mathrm{H}^{+}$-ATPase vacuolar pump, one of the most essential enzymes 92 present in almost all eukaryotic cells, is responsible for generating energy gradients in many membranes 93 and organelles (Wieczorek, 1992; Nelson et al., 2000; Wieczorek et al., 2009). Arginine kinase belongs to 94 a transferase protein family that catalyzes the transfer of a high-energy phosphate group from ATP to L95 arginine to yield phosphoarginine that is used for energy storage (Bragg et al., 2012; Kola et al., 2016). 96 These genes have been previously used as RNAi targets in exploratory studies in many different insects 97 and crop plants (Baum et al., 2007, Thakur et al., 2014; Kola et al., 2016); however, this is the first report 98 of silencing the Arginine kinase gene in a lepidopteran species.

99 Our results demonstrate the viability of using RNAi to control $T$. absoluta with delivery 100 approaches based either on dsRNA uptake by detached tomato leaflets or through transient expression 101 after leaf agro-infiltration, followed by infestation with pest larvae. Silencing of the insect V-ATPase and 102 AK genes after treatment with dsRNA resulted in increased larval mortality. Further, the development of 103 transgenic tomato lines expressing the hairpin version of these genes demonstrated that this approach can 104 adversely affect insect development and/or viability by reducing the expression of insect target genes.

\section{Methods}

\section{Biological material}

The colony of T. absoluta was originally established from two populations provided by the Insect Biology Laboratory of the Department of Entomology at ESALQ/USP (Piracicaba, SP, Brazil) and Bayer 


\section{Target gene selection}

Genes encoding a vacuolar V-ATPase and AK were chosen based on previous successful reports of

115 RNAi used for insect control (Baum et al. 2007; Zhao et al. 2008; Kola et al., 2016). Since no sequences

116 were available for T. absoluta genes, degenerated primers (Table S1) were developed based on conserved

117 amino acid sequence regions from aligned homologs of Aedes aegypti (GenBank accession V-ATPase:

118 XP_001659520.1), Bombyx mori (V-ATPase: NP_001091829.1; AK: NP_001037402.1), Drosophila

119 melanogaster (V-ATPase: NP_652004.2; AK: AAA68172.1), Helicoverpa armigera (AK: ADD22718.1),

120 Heliothis virescens (AK: ADE27964.1), Homalodisca vitripennis (AK: AAT01074.1), Manduca sexta (V-

121 ATPase: P31400.1), Spodoptera litura (AK: ADW94627.1) and Tribolium castaneum (V-ATPase

122 XP_976188.1; AK: EFA11419.1). Based on these orthologous genes, the complete V-ATPase A coding 123 sequence was estimated to be around $1850 \mathrm{bp}$, while the $A K$ coding sequence ranged from 1062 to 1476 124 bp.

\section{Tuta absoluta RNA extraction and cDNA synthesis}

126 Total RNA was extracted from $100 \mathrm{mg}$ of T. absoluta larvae at the four instar stages using TRIzol 127 (Invitrogen; Carlsbad, CA, USA). RNA was quantified spectrophotometrically and analyzed by 128 electrophoresis in 1\% denaturing agarose gels in MOPS buffer. Around $1 \mu \mathrm{g}$ of total RNA was treated 129 with DNase I and $20 \mathrm{U}$ of Ribolock (Fermentas; Burlington, Canada) at $37{ }^{\circ} \mathrm{C}$ for 30 min, with the 130 reaction stopped by adding EDTA $(50 \mathrm{mM})$ and heating to $65{ }^{\circ} \mathrm{C}$ for $10 \mathrm{~min}$. One microgram of DNase131 treated RNA samples was reversed transcribed in a total reaction volume of $20 \mu \mathrm{L}$ containing $500 \mu \mathrm{M}$ of 132 each dNTP, $2.5 \mu \mathrm{M}$ oligo dT, 5 mM DTT and 200 U SuperScript III (Invitrogen) in appropriate buffer at $13350{ }^{\circ} \mathrm{C}$ for $60 \mathrm{~min}$, followed by enzyme inactivation at $70{ }^{\circ} \mathrm{C}$ for $15 \mathrm{~min}$.

\section{Target gene amplification and cloning}

135 Target genes were amplified from cDNA using a nested PCR-based method with degenerate 136 primer pairs (Table S1) in a $20 \mu \mathrm{L}$ reaction volume containing $100 \mathrm{ng}$ of cDNA, $3 \mathrm{mM} \mathrm{MgCl} 2,100 \mu \mathrm{M}$ 
137 of each dNTP, $1 \mu \mathrm{M}$ of each primer and $2 \mathrm{U}$ of High Fidelity Taq DNA polymerase (Invitrogen) in the 138 appropriate buffer. Amplifications were done in a Veriti thermocycler (Applied Biosystems, Foster City, 139 CA, USA) programmed to cycle at $94{ }^{\circ} \mathrm{C}$ for $5 \mathrm{~min}$, followed by 35 cycles of $94{ }^{\circ} \mathrm{C}$ for $40 \mathrm{~s}, 45{ }^{\circ} \mathrm{C}$ for 60 $140 \mathrm{~s}, 72{ }^{\circ} \mathrm{C}$ for $60 \mathrm{~s}$ and a final cycle at $72{ }^{\circ} \mathrm{C}$ for $10 \mathrm{~min}$. The second reaction was run under the same 141 conditions as the first reaction using $1 \mu \mathrm{L}$ from the latter. Amplification products were analyzed by gel 142 electrophoresis and target fragments were excised, purified using a PureLink Quick gel extraction kit 143 (Invitrogen) and cloned into pGEM-T Easy vector (Promega; Madison, WI, USA) using standard 144 procedures. Identity was confirmed by sequencing three clones from each target gene in an ABI PRISM 1453130 (Applied Biosystems).

Cloning the target gene fragments as hairpins in the RNAi silencing vector

To clone the target gene fragments in the binary silencing vector pK7GWIWG2(I) (Karimi, et al., 148 2002) primers were synthesized to amplify fragments flanked by the recombination sequences attL1 and attL2 (Table S2). The amplification reactions contained $10 \mathrm{ng}$ of pGEM-T-cloned DNA, $200 \mu \mathrm{M}$ of each dNTP, $0.4 \mu \mathrm{M}$ of each primer and $2 \mathrm{U}$ of Phusion DNA polymerase (New England Biolabs; Ipswich, MA, USA) in a final reaction volume of $50 \mu \mathrm{L}$. Temperature cycling for amplification was programmed to start at $98{ }^{\circ} \mathrm{C}$ for $2 \mathrm{~min}$, followed by 35 cycles at $98{ }^{\circ} \mathrm{C}$ for $10 \mathrm{~s}, 60{ }^{\circ} \mathrm{C}$ for $15 \mathrm{~s}$ and $72{ }^{\circ} \mathrm{C}$ for $15 \mathrm{~s}$, with a final cycle at $72{ }^{\circ} \mathrm{C}$ for $5 \mathrm{~min}$. The amplified products were purified from agarose gels using QIAEX II gel extraction kits (Qiagen; Hilden, Germany), quantified, recombined into pK7GWIWG2(I) using LR clonase (Invitrogen) according to the manufacturer's instructions and transformed into TOP10 Escherichia coli cells. The presence of the insert was confirmed by amplification and the direction of insertion was verified by digestion and sequencing. Successful constructs were then transformed by heat shock into Agrobacterium tumefaciens GV3101/MP90 cells and confirmed by PCR.

dsRNA synthesis

pGEM-T Easy clones containing T. absoluta V-ATPase and $A K$ gene fragments were used as a 
162 Technologies, Carlsbad, CA, USA). Target sequences cloned into pGEM-T Easy were amplified with a T7

163 primer and a $\quad$ SP6 primer fused to a $\quad$ T7 sequence

164 (TAATACGACTCACTATAGGGATTTAGGTGACACTATAG) to operate as a T7 promoter for

165 bidirectional in vitro transcription. The amplification reactions contained $10 \mathrm{ng}$ of plasmid DNA, $1.5 \mathrm{mM}$

$166 \mathrm{MgCl}_{2}, 200 \mu \mathrm{M}$ of each dNTP, $0.5 \mu \mathrm{M}$ of each primer and $1.0 \mathrm{U}$ of Taq polymerase in a final reaction

167 volume of $20 \mu \mathrm{L}$. Temperature cycling for amplification started at $95{ }^{\circ} \mathrm{C}$ for $2 \mathrm{~min}$, followed by 35 cycles

168 of $15 \mathrm{~s}$ at $95{ }^{\circ} \mathrm{C}, 20 \mathrm{~s}$ at $60{ }^{\circ} \mathrm{C}, 30 \mathrm{~s}$ at $72{ }^{\circ} \mathrm{C}$, with a final extension at $72{ }^{\circ} \mathrm{C}$ for $5 \mathrm{~min}$. Amplified fragments

169 were run on and purified from $1 \%$ agarose gels as described above. Purified products were quantified by

170 fluorimetry and used for in vitro transcription reactions containing $100 \mathrm{ng}$ of target DNA, $7.5 \mathrm{mM}$ of each

171 ribonucleotide and $200 \mathrm{U}$ of MegaScript T7 in appropriate buffer in a final volume of $20 \mu \mathrm{L}$. The

172 reactions were run at $37^{\circ} \mathrm{C}$ for $16 \mathrm{~h}$, followed by the addition of $2 \mathrm{U}$ of DNase for $15 \mathrm{~min}$ at $37^{\circ} \mathrm{C}$. dsRNA

173 was purified by precipitation with $7.5 \mathrm{M} \mathrm{LiCl}(30 \mu \mathrm{L})$ at $-20{ }^{\circ} \mathrm{C}$ for $1 \mathrm{~h}$ followed by centrifugation $(12,000$

174 g, 15 min, $4{ }^{\circ} \mathrm{C}$ ). The RNA pellet was washed with $70 \%$ ethanol and resuspended in DEPC-treated water.

175 The green fluorescent protein (GFP) gene was used as a negative control. The vector pCAMBIA1302 was

176 used as a template to amplify a negative control GFP gene fragment (276 bp) with the specific primers

177 GFP-F (5’-TAATACGACTCACTATAGGGCAGTGGAGAGGGTGAA) and GFP-R (5’-

178 TAATACGACTCACTATAGGGTTGACGAGGGTGTCTC), both containing additional T7 sequences

179 (underlined). Similar transcription in vitro was done with this template.

\section{Labeling dsRNA to follow uptake by tomato leaflets and ingestion by T. absoluta}

In vitro transcription of dsRNA was done as described above, except that $2 \mu \mathrm{L}$ of Cy3-labelled riboCTP was added (Zhang et al. 2013). Fluorescently-labelled dsRNA was purified using a MEGAclear kit (Ambion; Carlsbad, CA, USA) and provided in solution to tomato leaflets at $500 \mu \mathrm{g} \mathrm{mL}^{-1}$. First instar larvae ( $n=15)$ were placed on the treated leaflets and collected $6 \mathrm{~h}$ or $24 \mathrm{~h}$ later for observation by confocal fluorescent microscopy with an AxioVision Zeiss LSM780-NLO microscope (Carl Zeiss AG).

\section{dsRNA delivery to T. absoluta larvae via feeding}



gene expression analysis in fed larvae, larval mortality or tomato tissue damage. In the first method, detached leaflets from 'Santa-Clara' tomatoes had their petioles immersed in $200 \mu \mathrm{L}$ of water containing either $5 \mu$ g of dsRNA from each target gene or a GFP control, in triplicate. Uptake of the dsRNA solution by the tomato leaflets took 3-4 h. Immediately after uptake, first instar larvae ( $n=50-100)$ were gently placed onto leaflets for feeding and individuals were sampled $24 \mathrm{~h}, 48 \mathrm{~h}$ and $72 \mathrm{~h}$ after initiation of feeding. Negative controls with dsRNA from the GFP gene sequence were run in parallel. The effects of RNAi on the larvae were evaluated by quantitative amplification of reversed transcripts (RT-qPCR) of each target gene compared to the control.

The second delivery method, termed here PITIGS (Plant-induced Transient Insect Gene Silencing), was based on the "in planta-induced transient gene silencing” (PITGS) method, an established method for silencing plant genes (Panwar et al., 2012). As a proof of concept, 'Santa Clara' tomato leaflets were infiltrated with Agrobacterium cells containing hairpin target gene fragments cloned into the pK7GWIWG2(I) vector or a similar hairpin expression construct for the GFP gene as a transient assay. Initially, to validate the potential of gene silencing in a transient assay, leaves were either infiltrated only with Agrobacterium GV3101/pMP90 cells containing an expression construct for enhanced GFP (eGFP) to visualize the GFP transient expression or in combination with another Agrobacterium line containing a GFP silencing construct (GFPi). The Agrobacterium suspensions were infiltrated into the abaxial side of the tomato leaves using a microsyringe and the treated area was marked with a permanent marker. Leaf tissues that had been agro-infiltrated with the eGFP or eGFP plus GFPi constructs were examined two days after treatment using a confocal fluorescent microscope (AxioVision Zeiss LSM780-NLO, Carl Zeiss AG, Germany) to monitor the degree of gene silencing based on eGFP expression. the V-ATPase hairpin constructs or with Agrobacterium cells carrying the GFPi construct as a negative control, in triplicate. The Agrobacterium cells were grown on LB medium containing gentamycin (25 $\mu \mathrm{g}$

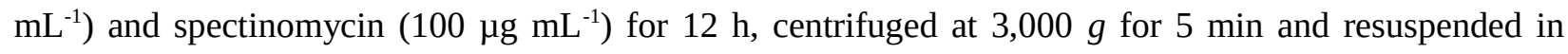


214 and $24 \mathrm{~h}, 48 \mathrm{~h}$ and $72 \mathrm{~h}$ later treated larvae and their respective controls were sampled for analysis of $\mathrm{V}$ -

215 ATPase and AK expression by RT-qPCR.

216 Feeding assays were also done to estimate larval mortality. Detached 'Santa Clara' leaflets had

217 their petioles immersed in an aqueous solution containing $1 \mu \mathrm{g}$ of dsRNA of each target gene (V-ATPase

218 or AK, plus GFP control), a procedure that was repeated daily for 10 days, with a total of $10 \mu \mathrm{g}$ being

219 provided to each leaflet. A total of 10 first instar larvae were placed to feed on these treated leaflets (in

220 triplicate) and larvae mortality was estimated after 5, 7, 10 and 24 days of treatment. Under the conditions

221 used here, the feeding cycle of T. absoluta lasted 10-12 days from larval emergence to pupae, and a total 222 of $c a$. 20-24 days for adults to emerge.

223 An additional assay was done using 'Santa Clara' tomato leaflets with the petiole immersed in 224 increasing amounts of dsRNA (total: 500, 1000 or $5000 \mathrm{ng}$ ) of the target genes (V-ATPase or AK) or GFP 225 negative control (in duplicate). Five larvae were placed on each leaflet and leaflets were photographed for 22611 days to visually assess the extent of damage.

\section{Quantitative amplification of reversed transcripts (RT-qPCR)} samples collected from the surviving larvae at specific time points for each experiment using a HighCapacity cDNA reverse transcription kit (Applied Biosystems) following the manufacturer's instructions, using $1 \mu \mathrm{g}$ of DNase-treated total RNA, random primers and $50 \mathrm{U}$ of MultiScribe reverse transcriptase in (Invitrogen) and $0.2 \mu \mathrm{M}$ of each gene-specific primer (Table S4) in a total volume of $10 \mu \mathrm{L}$. Amplifications were done starting at $50{ }^{\circ} \mathrm{C}$ for $10 \mathrm{~min}$ and $95{ }^{\circ} \mathrm{C}$ for $2 \mathrm{~min}$, followed by 40 three-step cycles of $95^{\circ} \mathrm{C}$ for $15 \mathrm{~s}, 60-61{ }^{\circ} \mathrm{C}$ for $25 \mathrm{~s}$ and $72{ }^{\circ} \mathrm{C}$ for $30 \mathrm{~s}$ in a Qiagen RotorGene-6000 (Qiagen). After amplification, melting curves were determined between $72{ }^{\circ} \mathrm{C}$ and $95{ }^{\circ} \mathrm{C}$. Reactions were done with biological replicates, technical triplicates and non-template controls. Primer efficiency was determined using a pool of cDNA in serial dilutions $\left(10,10^{-1}, 10^{-2}\right.$ and $\left.10^{-3}\right) . C_{Q}$ values were used to determine 
240 subunit 5 ribosomal protein), Rpl23A (large subunit 23A ribosomal protein) and $r R N A$ (Table S4).

241 Negative controls were larvae fed on GFP dsRNA.

\section{2 'Micro-Tom' genetic transformation with the RNAi silencing constructs}

243 The ATPase and AK silencing constructs were used to transform 'Micro-Tom' based on published 244 protocols (Pino et al., 2010). Cotyledon explants were obtained from 8-day old seedlings cultivated on MS 245 medium supplemented with sucrose $\left(30 \mathrm{~g} \mathrm{~L}^{-1}\right)$, B5 vitamins and $0.4 \mu \mathrm{M}$ naphthalene acetic acid (NAA) 246 (Pino et al., 2010). A single colony of Agrobacterium GV3101/MP90 (pK7GWIWG2(I)::ATPase-esaPTA 247 or pK7GWIWG2(I)::AK-KA) grown for two days on $3 \mathrm{~mL}$ of LB medium with spectinomycin (100 $\mathrm{mg} \mathrm{L}^{-}$ $\left.248{ }^{1}\right)$, rifampicin $\left(50 \mathrm{mg} \mathrm{L}^{-1}\right)$ and gentamycin $\left(25 \mathrm{mg} \mathrm{L}^{-1}\right)$ was inoculated into $50 \mathrm{~mL}$ of LB medium with the 249 same antibiotics and incubated overnight at $120 \mathrm{rpm}$ and $28{ }^{\circ} \mathrm{C}$. The suspensions were then centrifuged 250 (1,000 $\left.\mathrm{g}, 15 \mathrm{~min}, 20^{\circ} \mathrm{C}\right)$ and the pellet was re-suspended in liquid MS medium containing sucrose (30 $\mathrm{g} \mathrm{L}$ $25{ }^{1}{ }^{1}$ ), with the $\mathrm{OD}_{600 \mathrm{~mm}}$ adjusted to $0.2-0.3$. Acetosyringone $(100 \mu \mathrm{M})$ was added to the suspensions $10 \mathrm{~min}$ 252 before co-cultivation, which was done on the same semi-solid MS medium for two days in the dark at 25 $253{ }^{\circ} \mathrm{C}$. Explants were then transferred to fresh MS medium supplemented with B5 vitamins, sucrose (30 g L $\mathrm{L}^{-}$ $25{ }^{1}$ ), $5 \mu \mathrm{M}$ benzylamino purine (BAP), kanamycin $\left(100 \mathrm{mg} \mathrm{L}^{-1}\right)$ and timetin (300 $\left.\mathrm{mg} \mathrm{L}^{-1}\right)$ and maintained on 255 a $16 \mathrm{~h}$ photoperiod at $25{ }^{\circ} \mathrm{C}$ for three weeks. Subsequently, adventitious shoots $>5 \mathrm{~mm}$ long were 256 transferred to identical medium until roots developed and the plantlets were hardened ( two weeks), after 257 which they were moved to a greenhouse.

258 Genetic analysis of transgenic plants

259 Total DNA and RNA were extracted from putative transgenic plants using Trizol, by the Acid

260 Guanidinium Thiocyanate-phenol-chloroform extraction method (Chomczynski \& Sacchi 1987). 261 Confirmation of transgenesis was done by PCR using a 35S promoter sense primer 262 (GCACAATCCCACTATCCTTC) together with a target gene (ATPase and AK)-specific reverse primer 263 (Table S4). Reactions (final volume of $25 \mu \mathrm{L}$ ) contained $100 \mathrm{ng}$ of genomic DNA, $1.5 \mathrm{mM} \mathrm{MgCl} 2,0.2 \mu \mathrm{M}$ 264 of each dNTP, $0.1 \mu \mathrm{M}$ of each primer and $1.5 \mathrm{U}$ of Taq DNA polymerase in appropriate buffer 
265 (Fermentas). Amplification started at $95{ }^{\circ} \mathrm{C}$ for $2 \mathrm{~min}$, followed by 35 cycles of $15 \mathrm{~s}$ at $95{ }^{\circ} \mathrm{C}, 25 \mathrm{~s}$ at $60{ }^{\circ} \mathrm{C}$ 266 and $40 \mathrm{~s}$ at $72{ }^{\circ} \mathrm{C}$, with a final extension at $72{ }^{\circ} \mathrm{C}$ for $5 \mathrm{~min}$. The products were analyzed in $1 \%$ agarose 267 gels. To confirm transcript expression in transgenic plants, RT-PCR reactions were done using gene 268 specific primers for ATPase or AK (Table S4) together with primers for a tomato ubiquitin gene as an 269 endogenous reference gene. Reverse transcription was done with $1 \mu \mathrm{g}$ of DNase I-treated total RNA, 0.75 $270 \mu \mathrm{M}$ of gene-specific primers ( $V$-ATPase or $A K$ ), $0.75 \mu \mathrm{M}$ of ubiquitin primers, $0.5 \mathrm{mM}$ of each dNTP and $271200 \mathrm{U}$ of Revertaid (Fermentas) in a final volume of $20 \mu \mathrm{L}$. For RT-PCR, $1 \mu \mathrm{L}$ of cDNA, $1.5 \mathrm{mM} \mathrm{MgCl}_{2}$, $2720.2 \mathrm{mM}$ of each dNTP, $0.1 \mu \mathrm{M}$ of each primer and $1.5 \mathrm{U}$ of Taq DNA polymerase (Fermentas) were mixed 273 in a final volume of $25 \mu \mathrm{L}$ and amplified at $95{ }^{\circ} \mathrm{C}$ for $2 \mathrm{~min}$, followed by 35 cycles at $95{ }^{\circ} \mathrm{C}$ for $15 \mathrm{~s}, 60{ }^{\circ} \mathrm{C}$ 274 for $30 \mathrm{~s}$ and $72{ }^{\circ} \mathrm{C}$ for $20 \mathrm{~s}$. Amplification products were examined by gel electrophoresis.

275 To specifically detect siRNA expressed in transgenic plants, a stem-loop pulsed RT-PCR was done 276 using the protocol described by Varkonyi-Gasic et al. (2007). Initially, the introduced gene fragment 277 sequences were analyzed with a software for virtual prediction of siRNA (Rice et al., 2000). Stem-loop 278 primers specific for two virtually predicted siRNA for each gene, gene-specific primers and a universal 279 primer (Varkonyi-Gasic et al., 2007) were obtained (Table S5). As an endogenous control, primers for 280 microRNA156 (MIR156) were also developed based on sequences available at miRBASe (Kozomara \& 281 Griffiths-Jones, 2011). Reverse transcription reactions used $0.05 \mu \mathrm{M}$ of stem-loop primers and $1 \mu \mathrm{g}$ of DNase-treated total RNA that were heated to $70{ }^{\circ} \mathrm{C}$ for $10 \mathrm{~min}$ and chilled to $4{ }^{\circ} \mathrm{C}$ for $10 \mathrm{~min}$. Subsequently, $3 \mathrm{mM} \mathrm{MgCl}$, $0.25 \mathrm{mM}$ of each dNTP and $200 \mathrm{U}$ of Revertaid (Fermentas) in appropriate buffer were added to a final volume of $20 \mu \mathrm{L}$. The reaction was run at $16{ }^{\circ} \mathrm{C}$ for $30 \mathrm{~min}$, followed by 60 cycles at $30{ }^{\circ} \mathrm{C}$ for $30 \mathrm{~s}$, at $42{ }^{\circ} \mathrm{C}$ for $30 \mathrm{~s}$ and $50{ }^{\circ} \mathrm{C}$ for $1 \mathrm{~s}$, with a final step at $85{ }^{\circ} \mathrm{C}$ for 5 min to inactivate the enzyme. Amplification was then done in reactions consisting of $1 \mu \mathrm{L}$ of $\mathrm{cDNA}, 1.5 \mathrm{mM} \mathrm{MgCl}_{2}, 0.2$ $\mathrm{mM}$ of each dNTP, $0.2 \mu \mathrm{M}$ of each primer and $1.5 \mathrm{U}$ of Taq DNA polymerase in appropriate buffer

288 (Fermentas). Temperature cycling started at $94{ }^{\circ} \mathrm{C}$ for $2 \mathrm{~min}$, followed by 35 cycles at $94{ }^{\circ} \mathrm{C}$ for $15 \mathrm{~s}$ and $28960{ }^{\circ} \mathrm{C}$ for $1 \mathrm{~min}$. The products were examined after separation on 3\% agarose gels. 
controls had their petioles immersed in water. Ten recently hatched larvae were then allowed to feed on the leaves, which were photographed for seven days to monitor leaf tissue damage. Pupae were collected at the end of the larval cycle for counting and weighing.

\section{Results}

\section{Target gene isolation from T. absoluta and dsRNA transcription in vitro}

Since little genomic information is available for T. absoluta, we conducted target gene fragment cloning using degenerated primers for both target genes (estimated coding sequence of $\sim 1,850$ bp for $V$ ATPase and $~ 1,065$ bp for $A K$ ) by using nested PCR (Table S1). The final amplification products were run on agarose gels and fragments for both genes were purified and cloned. Three positive clones were sequenced in both directions for each target gene. The consensus sequence assembled from the three clones contained 285 bp for V-ATPase [GenBank: KM591219] and 262 bp for AK [GenBank: KM591220]. The sequences were conceptually translated and aligned to homologs from other species (Fig. S1); both sequences displayed conserved domains (GenBank:cd01134 for V-ATPase and GenBank:cd07932 for $A K)$.

In all RNAi assays, the same regions of the target and green fluorescent protein (GFP) control genes were used, either by in vitro transcription of the dsRNA or by transient/stable transgenesis.

\section{dsRNA delivery methods for T. absoluta in tomato}

\section{Leaf uptake of dsRNA and larval ingestion}

To overcome the lack of a suitable artificial diet for T. absoluta, we used alternative methods to deliver dsRNA to the insect larvae in order to facilitate the rapid screening of candidate target genes. The first approach involved supplying dsRNA transcribed in vitro to tomato leaflets by petiole uptake. Detached tomato leaves absorbed a solution of dsRNA transcribed in vitro by the petioles and first instar larvae subsequently fed on these treated leaves. To determine whether the dsRNA could be successfully absorbed and transported to the leaf laminae and then be ingested by the insect to reach its digestive tract, 
316

Cy3-lableled (red fluorescence) dsRNA fragments of V-ATPase transcribed in vitro were provided in solution to detached tomato leaflets.

The treated leaves and the feeding larvae were imaged by confocal microscopy $6 \mathrm{~h}$ or $24 \mathrm{~h}$ after treatment (Fig. 1 and Fig. S2). Labelled dsRNA species were already strongly detected in the leaflet petiole and blade (mid-rib and lateral veins) of the leaflets $6 \mathrm{~h}$ after treatment (Fig. 1Ab). After 24 h, Cy3labeled RNA molecules were detected throughout the leaf blade (Fig. 1Ad and Fig. S2). With time, Cy3labeled RNA molecules accumulated at the leaf margin until saturation was reached in certain areas (Fig. 1Ad).

We then imaged larvae fed on treated or untreated leaflets using the 488 channel (green fluorescence) to detect chlorophyll auto-fluorescence, indicative of plant tissue ingestion by the larvae, and the 555 channel (red fluorescence) to detect Cy3 fluorescence (Fig. 1B). In both treatments, green fluorescence was detected throughout the larval digestive tract (Fig. 1Bb), indicating that the larvae fed normally under both circumstances. However, larvae fed on dsRNA-treated leaflets showed a strong Cy3 signal in the digestive tract, indicating the presence of leaflet-absorbed Cy3-labeled RNA molecules in the gastric caeca of the midgut (Fig. 1Bc).

\section{Plant Induced Transient Insect Gene Silencing (PITIGS)}

We took advantage of the transient expression by Agrobacterium infiltration to develop a system to mimic stable transgenesis in which plant cells expressing hairpin versions of the target gene to transcribe the dsRNA targeting insect specific genes. This approach is based on PITGS (Plant Induced Transient Gene Silencing), an established method for silencing plant genes (Panwar et al., 2012). We named this approach PITIGS (Plant Induced Transient Insect Gene Silencing). As a proof of concept, we infiltrated 'Santa Clara' tomato leaves with two Agrobacterium strains: one containing an expression cassette for enhanced GFP expression (eGFP strain) and another in which a $400 \mathrm{bp}$ fragment of $e G F P$ was cloned into a binary expression vector as inverted repeats in order to transcribe a hairpin version (dsRNA) of the eGFP gene (GFPi strain). 

infiltration (Fig. S3c).

To employ PITIGS for the target genes, fragments of V-ATPase and AK were cloned into a binary

vector as a hairpin-expressing cassette and agro-infiltrated into 'Santa Clara' tomato leaves. The cloned

fragments were amplified with primers flanked by attL1 and attL2 sequences (Table S2) to enable direct recombination with the binary vector pK7GWIWG2(I) (Karimi et al., 2002).

\section{Effect of RNAi on target gene expression}

For both RNAi delivery methods, larvae were allowed to feed exclusively on RNAi-treated leaflets (dsRNA uptake or agro-infiltration) and collected 24 h, 48 h and 72 h later. The relative expression of $V$-ATPase and $A K$ was quantified by RT-qPCR.

Larvae fed on leaflets treated by the dsRNA uptake delivery method showed a significant decrease in transcript accumulation for both genes $48 \mathrm{~h}$ and $72 \mathrm{~h}$ after treatment ( $\sim 40 \%$ reduction at $72 \mathrm{~h}$ after treatment) (Fig. 2A). Larvae fed on agro-infiltration leaflets showed a decrease in transcript accumulation at all time points, with the highest decrease occurring $72 \mathrm{~h}$ after treatment, ( $35 \%$ reduction for V-ATPase and $40 \%$ reduction for $A K$ ) (Fig. 2B).

Considering that both dsRNA delivery approaches resulted in similar gene silencing effects, subsequent experiments were done using only the leaf dsRNA uptake delivery method.

\section{Effect of RNAi on larval mortality}

To determine the effect of RNAi on larval mortality, T. absoluta larvae were allowed to feed on single leaflets $(n=3)$ that had absorbed $10 \mu \mathrm{g}$ of dsRNA from V-ATPase, AK or GFP prior to the start of the feeding essay. Larvae were then sampled after five, seven and ten days of treatment and an additional 
365 pupal sample was collected after 24 days. Larval mortality was significantly higher in larvae fed on

366 leaflets that absorbed dsRNA of either target gene when compared to the GFP control at all time points,

367 with an additional increase over time (Fig. 3). By day 24, mortality had reached an average of 50\% for $V$ -

368 ATPase and $43 \%$ for AK compared to $17 \%$ for the GFP control (Fig. 3). Independent experiments using

369 different total amounts of dsRNA in the leaflets yielded similar results (not shown), with no pleiotropic

370 effect observed when using higer concentrations of dsRNA for the target genes. Evaluation of larvae after

37111 days of treatment (Fig. S4a-c) and at the pupal stage (Fig. S4d-f) revealed that larvae fed on RNAi-

372 treated leaflets displayed developmental delay, reduced body size, external morphologies of the $3^{\text {rd }}$ instar

373 stage (when $4^{\text {th }}$ instar was expected) (Fig. S4a-c), failure to pupate (Fig. S4d-f), and failure to emerge as

374 adults (data not shown).

\section{Effect of RNAi on tomato leaf damage}

We next assessed whether the gene silencing and larval mortality observed for both RNAi target genes resulted in less herbivory by T. absoluta on tomato leaves. After 11 days of exposure to T. absoluta, leaflet blades treated with increasing amounts of dsRNA (total: 500, 1000 or $5000 \mathrm{ng}$ ) of the target genes (V-ATPase or AK) (Fig. 4c-f) were visibly less damaged by larval herbivory when compared to leaflets treated with GFP dsRNA (Fig. 4a,b); the observed protective effect appeared to be dose-dependent (Fig. 4c-f). A protective effect was seen even at lower doses of dsRNA treatment, particularly for V-ATPase (Fig. 4d).

\section{RNAi transgenic tomato plants}

To examine the effects of constitutive RNAi in planta, pK7GWIWG2(I) plasmids containing $V$ ATPase or AK employed in the Agrobacterium transient hairpin expression were used to stably transform 'Micro-Tom' tomato plants. 'Micro-Tom' plants were successfully transformed in three independent experiments (Table S3). The efficiency of transformation ranged from 3.5\% to $18.9 \%$ and varied among gene constructs. To characterize the events, 13 plants derived from 11 events of the V-ATPase construct transformation were analyzed by PCR amplification and eight events were positive for the transformation. 
390 From $A K$ constructs, nine plants from six events were characterized and all were positive. The confirmed 391 transgenic plants (eight $V$-ATPase and nine $A K$ ) were analyzed for the presence of the full transcript by 392 RT-PCR; all V-ATPase plants plus six AK plants (\#2.1, \#2.2, \#2.3, \#3, \#5 and \#6) showed the presence of

393 the respective transcript (Fig. S5A). The plants were also analyzed for the presence of a potential siRNA 394 derived from the gene fragments inserted by stem-loop pulsed RT-PCR using specific primers (Table S4), 395 and all plants from both target genes presented the expected siRNA, except for AK event \#4 (Fig. S5B). 396 Absence of the transcript in $A K \# 4$ was also demonstrated by RT-PCR. Conversely, events $A K \# 1.1$ and 397 AK\#1.2 did not show the presence of the transcript by RT-PCR, but the stem-loop pulsed RT-PCR assay 398 revealed the presence of the expected siRNA.

\section{Larval survival and leaf damage in RNAi transgenic tomatoes}

To test whether RNAi transgenic plants would promote larval mortality and protect against herbivory, T. absoluta larvae were allowed to feed on $\mathrm{T}_{0}$ transgenic 'Micro-Tom' leaves until emergence as adults. Larvae fed on these leaves were collected and larval mortality was evaluated by counting survivors and by visually detecting deleterious larval phenotypes based on larval size and weight. When fed on nontransgenic control plants, $100 \%$ of the larvae developed normally and reached the pupal stage. Conversely, feeding on RNAi transgenic plants resulted in a significant increase in larval mortality that ranged from 30\% in events ATPase1.1 and ATPase7 to 40\% in ATPase 9 and AK 1.1 (Fig. 5A). The effect of RNAi was also assessed by comparing larval weight between treatments. Larvae fed on non-transgenic controls had a mean weight of $3.5 \mathrm{mg}$, while those fed on leaves of the different RNAi transgenic plants had a mean weight of 1.7 to $2.4 \mathrm{mg}$ (Fig. 5B).

Visual analysis of leaves from the different treatments revealed a clear protective effect against

\section{Discussion}


The tomato leafminer T. absoluta can cause up to $100 \%$ damage in tomato plants in various regions and under diverse cultivation systems (Desneux et al., 2010; Urbaneja et al., 2013). Resistance to insecticides has been reported for this pest, making the development of alternative means for control even more urgent (Urbaneja et al., 2013; Campos et al., 2014). In this work, we demonstrated that RNAi for VATPase and $A K$, known RNAi target genes among pest insects, significantly reduces target gene expression, increases larval mortality and reduces leaf damage caused by larval herbivory. Both genes studied here have been previously used as RNAi target genes in studies with various agricultural pests, but this is the first report on $A K$ silencing in a lepidopteran species.

In this work, we used two RNAi delivery methods to investigate T. absoluta gene silencing for .

424 The 'leaf-absorbed dsRNA' delivery is based on the leaflet uptake of dsRNA transcribed in vitro, whereas 425 the PITIGS is based on larval feeding on tomato leaflets containing dsRNA transcribed in planta. The 426 'leaf-absorbed dsRNA' delivery avoids cloning steps into specific vectors and allows a better control of 427 provided dsRNA amounts in the leaves, while PITGS offers a more realistic trigger of the RNAi 428 machinery in transgenic plants, since the dsRNA hairpin molecule will be transcribed and processed by 429 the plant cells, as expected in transgenic plants. Noteworthy, the same gene construct can subsequently be 430 used to transform the host plant. 'Leaf-absorbed dsRNA' delivery has been previously used for RNAi431 based gene silencing in the sap-sucking B. tabaci (Luan et al., 2013). PITIGS is based on a known gene 432 silencing delivery method (PITGS; Panwar et al., 2012), but adapted here to present a novel plantproducing RNAi response targeting insect-specific genes.

Our work addresses the need of developing novel delivery methods to confer reliable method to provide dsRNA to insects and test the effectiveness of the target gene in conferring pest resistance or improved plant viability. The optimization of RNAi conditions requires an efficient, high throughput delivery system that addresses specificity and effectiveness of the target gene, optimal dsRNA size and dose response or phenotypic effect. Traditionally, RNAi target genes are screened and evaluated by adding dsRNA to artificial diets offered to insect larvae (Terenius et al., 2011; Zhang et al., 2012). However, artificial diets are not readily available for many of the important pest species, including T. absoluta 441 (Urbaneja et al., 2013), hence the need for alternative delivery methods to overcome this limitation. To 
442 date, two alternative methods for oral feeding have been used to deliver dsRNA to insects: microinjection 443 into the hemocoel and soaking (Price \& Gatehouse, 2008; Gu \& Knipple, 2013). However, despite being 444 very straightforward methods, RNAi-based pest control still relies mostly on host-insect interactions such 445 that delivery methods based on ingestion would be more appropriate for this use of RNAi. The final delivery of RNAi molecules in crop protection requires a delivery system to provide dsRNA continuously as a diet component to be ingested by the insects, either through transgenic plants expressing hairpin versions of target genes or by spraying dsRNA, currently a more costly option (Katoch et al., 2013). gene silencing, increased larval mortality and protection against herbivory. These methods have an advantage over dsRNA delivery via an artificial diet since they allow the use of natural feeding material (host plant leaves) ingested during herbivory. Notably, both delivery methods resulted in enhanced RNAi effects over time, with the greatest reduction in transcript accumulation for $V$-ATPase and $A K$ observed at the latest sampling time points (Figs. 2 and 3), and larval mortality also increasing gradually in time (Fig. 3). This time-dependent RNAi response may reflect the systemic dissemination of RNAi or simply the prolonged effect of gene silencing on larval survival. Interestingly, insects may lack an siRNA signal amplification mechanism, as indicated by the apparent absence of a canonical RNA-dependent RNA polymerase (RdRP) in this phylum (Gordon \& Waterhouse 2007; Camargo et al. 2015), and this could significantly affect the source-to-signal ratio of the RNAi effects in pest insects. The 'leaf-absorbed dsRNA' delivery method also allowed us to assess the dose dependence of the RNAi response in leaf protection, with greater protection being observed in leaflets that absorbed the highest dsRNA dose tested (5000 ng) for both target genes. and then moved to lateral veins (Fig. 1Ad), as expected for soluble molecules flowing in the leaf 
469

470

471 survival

phenomenon suggested that the RNAi molecules were initially distributed throughout the entire leaf vasculature, including the end of the vasculature tracks located at the leaf margins. Upon saturation of the vascular track, the molecules started to diffuse to the leaf lamina and until they covered the entire leaf.

We used the newly described 'PITIGS' delivery method to ask whether exogenous hairpin molecules would be processed by the plant RNAi machinery or maintained as dsRNA until ingested by the larvae. Infiltration of tomato leaves with Agrobacterium cells carrying GFP-expressing and -silencing cassettes resulted in exogenous gene silencing in planta. These results indicates that exogenous GFPdsRNA molecules transcribed in planta are processed by the plant RNAi machinery, strongly suggesting that the RNAi mechanism that resulted in eGFP silencing in plant leaves would similarly process the insect-specific dsRNA into siRNA that would later be ingested by the larvae during feeding.

The effects of RNAi on gene silencing, larval mortality and leaf damage using both RNAi delivery methods led us to establish transgenic tomatoes plants carrying the same expression construct used in the PITIGS method. Tuta absoluta larvae fed on $\mathrm{T}_{0}$ transgenic 'Micro-Tom' leaves weighted less, showed increased mortality and caused less damage to the tomato leaves. ATPase and AK are both required genes for metabolism and homeostasis in lepidopterans, affecting development, moulting and 
feeding on ATPase and $A K$ dsRNA-containing tomato leaves, suggesting that transgenesis could be a useful final delivery method for RNAi-mediated control of T. absoluta. canonical RdRP was found, an occurrence widely described for insects (Terenius et al., 2011; Gu \& Knipple, 2013; Katoch et al., 2013 Zhang et al., 2013; Scott et al., 2013).

With the increase in T. absoluta resistance to currently used insecticides (Urbaneja et al., 2013; Campos et al., 2014), the application of RNAi could be a promising approach for controlling this insect. The major application of our findings is to provide alternative delivery methods for RNAi-based cropprotection technologies. In the absence of an artificial diet, the two alternative delivery systems can be used to evaluate the effectiveness of potential gene targets. We also demonstrated that transgenesis is a potentially useful final delivery method for RNAi-mediated control of T. absoluta. This method could provide a useful starting point for the development of alternatives to conventional pesticides.

\section{References}

Baum JA, Bogaert T, Clinton W, Heck GR, Feldmann P, Ilagan O 2007. Control of coleopteran insect pests through RNA interference. Nature Biotechnol 25:1322-1326.

Bendahmane A, Querci M, Kanyuka K, Baulcombe DC. 2000. Agrobacterium transient expression system as a tool for the isolation of disease resistance genes: application to the Rx2 locus in potato. Plant J. M. 2012. Identification and characterization of a putative arginine kinase homolog from 
514

Camargo R, Herai R, Santos L, Bento F, Lima J, Marques-Souza H, Figueira A 2015. De novo transcriptome assembly and analysis to identify potential gene targets for RNAi-mediated control of the tomato leafminer (Tuta absoluta). BMC Genomics 16:635.

Campos MR, Rodrigues ARS, Silva WM, Silva TBM, Silva VRF, Guedes RNC, Siqueira HAA. 2014. Spinosad and the tomato borer Tuta absoluta: a bioinsecticide, an invasive pest threat, and high insecticide resistance. PLoS ONE 9:e103235. DOI: 10.1371/journal.pone.0103235.

Cifuentes D, Chynoweth R, Bielza P. 2011. Genetic study of Mediterranean and South American populations of tomato leafminer Tuta absoluta (Povolny, 1994) (Lepidoptera: Gelechiidae) using ribosomal and mitochondrial markers. Pest Manag. Sci. 67:1155-1162. DOI: 10.1002/ps.2166.

Chikate YR, Dawkar VV, Barbole RS, Tilak PV, Gupta VS, Giri AP 2016. Data in Brief. Data in Brief 7:1602-1605. DOI: 10.1016/j.dib.2016.04.026.

Chomczynski, P. \& Sacchi, N. Single-step method of RNA isolation by acid guanidinium thiocyanatephenol-chloroform extraction. Anal. Biochem. 162, 156-159 (1987).

Coleman AD, Pitino M, Hogenhout SA 2014. Silencing of aphid genes by feeding on stable transgenic Arabidopsis thaliana. Methods in molecular biology (Clifton, NJ) 1127:125-136. DOI: 10.1007/978-1-62703-986-4_10.

Coleman AD, Wouters RHM, Mugford ST, Hogenhout SA 2015. Persistence and transgenerational effect of plant-mediated RNAi in aphids. Journal of Experimental Botany 66:541-548. DOI: 10.1093/jxb/eru450.

Desneux N, Wajnberg E, Wyckhuys KAG, Burgio G, Arpaia S, Narváez-Vasquez CA, González-Cabrera J, Catalán Ruescas D, Tabone E, Frandon J, Pizzol J, Poncet C, Cabello T, Urbaneja A. 2010. Biological invasion of European tomato crops by Tuta absoluta: ecology, geographic expansion and prospects for biological control. J. Pest. Sci. 83:197-215. DOI:10.1007/s10340-010-0321-6.

Desneux N, Luna MG, Guillemaud T, Urbaneja A. 2011. The invasive South American tomato pinworm, Tuta absoluta, continues to spread in Afro-Eurasia and beyond: the new threat to tomato world production. J. Pest Sci. 84:403-408. DOI: 10.1007/s10340-011-0398-6.

Fishilevich E, Vélez AM, Storer NP, Li H, Bowling AJ, Rangasamy M, Worden SE, Narva KE, Siegfried BD 2016. RNAi as a management tool for the western corn rootworm, Diabrotica virgifera virgifera. Pest management science 72:1652-1663. DOI: 10.1002/ps.4324. 
543 Forgac, M., 2007. Vacuolar ATPases: rotary proton pumps in physiology and pathophysiology. Nature 544 Reviews Molecular Cell Biology, 8(11), pp.917-929.

545 Gordon, K. \& Waterhouse, P.M., 2007. RNAi for insect-proof plants. Nature Biotechnol, 25, pp.12315461232.

547 Grimsley N, Hohn T, Davies JW, Hohn B. 1987. Agrobacterium-mediated delivery of infectious maize 548 streak virus into maize plants. Nature 325:177-179. DOI 10.1038/325177a0.

549 Gu L, Knipple D C. 2013. Recent advances in RNA interference research in insects: Implications for 550 future insect pest management. Crop Protection 45:36-40. DOI: 10.1016/j.cropro.2012.10.004.

Hannon GJ. 2002. RNA interference. Nature 418:244-251. DOI:10.1038/418244a.

Karimi M, Inze D, Depicker A. 2002. GATEWAYTM vectors for Agrobacterium-mediated plant transformation. Trends Plant Sci. 7:193-195. DOI: 10.1016/S1360-1385(02)02251-3.

Katoch R, Sethi A, Thakur N, Murdock LL. 2013. RNAi for insect control: current perspective and future challenges. Appl. Biochem. Biotechnol. 171:847-873. DOI: 10.1007/s12010-013-0399-4.

Khan AM, Ashfaq M, Kiss Z, Khan AA, Mansoor S, Falk BW 2013. Use of Recombinant Tobacco Mosaic Virus To Achieve RNA Interference in Plants against the Citrus Mealybug, Planococcus citri (Hemiptera: Pseudococcidae). PloS one 8:e73657. DOI: 10.1371/journal.pone.0073657.s001.

Koch A, Kogel KH. 2014. New wind in the sails: improving the agronomic value of crop plants through RNAi-mediated gene silencing. Plant Biotechnol. J. 12:821-831. DOI: 10.1111/pbi.12226.

Kola VSR, Renuka P, Madhav MS, Mangrauthia SK 2015. Key enzymes and proteins of crop insects as candidate for RNAi based gene silencing. Frontiers in physiology 6:1. DOI: 10.3389/fphys.2015.00119.

Kozomara A, Griffiths-Jones S. 2011. miRBase: integrating microRNA annotation and deep-sequencing data. Nucleic Acids Res. 39:D152-D157.DOI: 10.1093/nar/gkq1027.

Leckie BM, Stewart Jr CN. 2010. Agroinfiltration as a technique for rapid assays for evaluating candidate insect resistance transgenes in plants. Plant Cell Rep. 30:325-334. DOI: 10.1007/s00299-010-0961-

Li, C. \& Xia, Y., 2012. Vacuolar ATPase subunit H is essential for the survival and moulting of Locusta migratoria manilensis. Insect molecular biology, 21(4), pp.405-413. 
572

piercing-sucking and stem-borer insect pests. Plant, Cell \& Environment 38:2277-2285. DOI: 10.1111/pce.12546.

Li J, Chen Q, Lin Y, Jiang T, Wu G, Hua H 2011. RNA interference in Nilaparvata lugens (Homoptera: Delphacidae) based on dsRNA ingestion. Pest management science 67:852-859. DOI: $10.1002 / p s .2124$.

Livak KJ, Schmittgen TD. 2001. Analysis of relative gene expression data using real-time quantitative PCR and the 2(- $\Delta \Delta \mathrm{Ct})$ method. Methods 25:402-408.DOI: 10.1006/meth.2001.1262.

Luan JB, Ghanim M, Liu SS, Czosnek H. 2013. Silencing the ecdysone synthesis and signaling pathway genes disrupts nymphal development in the whitefly. Insect Biochem. Mol. Biol. 43:740-746. DOI: 10.1016/j.ibmb.2013.05.012.

Li H, Guan R, Guo H, Miao X 2015. New insights into an RNAi approach for plant defence against piercing-sucking and stem-borer insect pests. Plant, Cell \& Environment 38:2277-2285. DOI: 10.1111/pce.12546.

Li J, Chen Q, Lin Y, Jiang T, Wu G, Hua H 2011. RNA interference in Nilaparvata lugens (Homoptera: Delphacidae) based on dsRNA ingestion. Pest management science 67:852-859. DOI: 10.1002/ps.2124.

Mao YB, Cai WJ, Wang JW, Hong GJ, Tao XY, Wang LJ, Huang YP, Chen XY. 2007. Silencing a cotton bollworm P450 monooxygenase gene by plant-mediated RNAi impairs larval tolerance of gossypol. Nat. Biotechnol. 25:1307-1313 DOI: 10.1038/nbt1352.

Mao YB, Tao XY, Xue XY, Wang LJ, Chen XY. 2011. Cotton plants expressing CYP6AE14 doublestranded RNA show enhanced resistance to bollworms. Transgenic Res. 20:665-673. DOI: 10.1007/s11248-010-9450-1.

Mao J, Zhang P, Liu C, Zeng F 2015. Pesticide Biochemistry and Physiology. Pesticide biochemistry and physiology 118:71-76. DOI: 10.1016/j.pestbp.2014.11.013.

Nelson N, Perzov N, Cohen A, Hagai K, Padler V, Nelson H. 2000. The cellular biology of proton-motive force generation by V-ATPases. J. Exp. Biol. 203:89-95.

Paim RMM, Araujo RN, Lehane MJ, Gontijo NF, Pereira MH 2012. Application of RNA interference in triatomine (Hemiptera: Reduviidae) studies. Insect Science 20:40-52. DOI: 10.1111/j.17447917.2012.01540.x.

Panwar V., McCallum B., Bakkeren G. 2012. Endogenous silencing of Puccinia triticina pathogenicity 
602

603

604

605

606

607

608

609

610

611

612

613

614

615

616

617

618

619

620

621

622

623

624

625

626

627

628

629

630

631

genes through in planta-expressed sequences leads to the suppression of rust diseases on wheat. Plant J. 73:521-532. DOI:10.1111/tpj.12047.

Pino LE, Lombardi-Crestana S, Azevedo MS, Scotton DC, Borgo L, Quecini V, Figueira A, Peres LEP. 2010. The Rg1 allele as a valuable tool for genetic transformation of the tomato`Micro-Tom’model system. Plant Methods 6:23. DOI: 10.1186/1746-4811-6-23.

Pitino M, Coleman AD, Maffei ME, Ridout CJ, Hogenhout SA. 2011. Silencing of aphid genes by dsRNA feeding from plants. PLoS ONE 6:e25709. DOI:10.1371/journal.pone.0025709.

Price D, Gatehouse JA. 2008. RNAi-mediated crop protection against insects. Trends Biotechnol. 26:393400. DOI: 10.1016/j.tibtech.2008.04.004.

Qi X-L, Su X-F, Lu G-Q, Liu C-X, Liang G-M, Cheng H-M 2015. The effect of silencing arginine kinase by RNAi on the larval development of Helicoverpa armigera. Bulletin of entomological research 105:555-565. DOI: 10.1017/S0007485315000450.

Qiu J, He Y, Zhang J, Kang K, Li T, Zhang W 2016. Discovery and functional identification of fecundityrelated genes in the brown planthopper by large-scale RNA interference. Insect molecular biology. DOI: $10.1111 / \mathrm{imb} .12257$.

Rice P, Longden I, Bleasby A. 2000. EMBOSS: the European molecular biology open software suite. Trends Genet. 16:276-277.

Scott JG, Michel K, Bartholomay LC, Siegfried BD, Hunter WB, Smagghe G, Zhu KY, Douglas AE 2013. Journal of Insect Physiology. Journal of insect physiology 59:1212-1221. DOI: 10.1016/j.jinsphys.2013.08.014.

Silva WM, Berger M, Bass C, Balbino VQ, Amaral MHP, Campos MR, Siqueira HAA 2015. Pesticide Biochemistry and Physiology. Pesticide biochemistry and physiology 122:8-14. DOI: 10.1016/j.pestbp.2015.01.011.

Terenius O, Papanicolaou A, Garbutt JS, Eleftherianos I, Huvenne H, et al., 2011. RNA interference in Lepidoptera: an overview of successful and unsuccessful studies and implications for experimental design. J. Insect Physiol. 57: 231-245. DOI: 10.1016/j.jinsphys.2010.11.006.

Tian G, Cheng L, Qi X, Ge Z, Niu C, Zhang X, Jin S 2015. Transgenic Cotton Plants Expressing Doublestranded RNAs Target HMG-CoA Reductase (HMGR) Gene Inhibits the Growth, Development and Survival of Cotton Bollworms. Int J Biol Sci 11:1296-1305. DOI: 10.7150/ijbs.12463. 
632

resistance in transgenic tobacco plants expressing double stranded RNA of V-ATPase a gene. PLoS ONE 9:e87235. DOI 10.1371/journal.pone.0087235.

Tonnang HEZ, Mohamed SF, Khamis F, Ekesi S 2015. Identification and Risk Assessment for Worldwide Invasion and Spread of Tuta absoluta with a Focus on Sub-Saharan Africa: Implications for Phytosanitary Measures and Management. PloS one 10:e0135283. DOI: 10.1371/journal.pone.0135283.t002.

Tzin V, Yang X, Jing X, Zhang K, Jander G, Douglas AE 2015. Journal of Insect Physiology. Journal of insect physiology 79:105-112. DOI: 10.1016/j.jinsphys.2015.06.006.

Urbaneja A, Desneux N, Gabarra R, Arno J, Gonzalez-Cabrear J, Mafra-Neto A. 2013. Biology, ecology and management of the South American tomato pinworm, Tuta absoluta, in potential invasive pests of agricultural crops. In: Peña JE, ed. Potential invasive pests of agricultural crops. CABI, 98-132. DOI: $10.1079 / 9781845938291.0098$.

Varkonyi-Gasic E, Wu R, Wood M, Walton EF, Hellens RP. 2007. Protocol: a highly sensitive RT-PCR method for detection and quantification of microRNAs. Plant Methods 3:12. DOI: 10.1186/17464811-3-12.

Wang J, Gu L, Ireland S, Garczynski SF, Knipple DC 2015. Phenotypic screen for RNAi effects in the codling moth Cydia pomonella. Gene 572:184-190. DOI: 10.1016/j.gene.2015.07.006.

Wieczorek H 1992. The insect V-ATPase, a plasma membrane proton pump energizing secondary active transport: molecular analysis of electrogenic potassium transport in the tobacco hornworm midgut. The Journal of experimental biology 172:335-343.

Wieczorek H, Beyenbach KW, Huss M, Vitavska O 2009. Vacuolar-type proton pumps in insect epithelia. Journal of Experimental Biology 212:1611-1619. DOI: 10.1242/jeb.030007.

Xiong Y, Zeng H, Zhang Y, Xu D, Qiu D. 2013. Silencing the HaHR3 gene by transgenic plant-mediated RNAi to disrupt Helicoverpa armigera development. Int. J. Biol. Sci. 9: 370-381. DOI: 10.7150/ijbs.5929.

Xu L, Duan X, Lv Y, Zhang X, Nie Z, Xie C, Ni Z, Liang R. 2014. Silencing of an aphid carboxylesterase gene by use of plant-mediated RNAi impairs Sitobion avenae tolerance of Phoxim insecticides. Transgenic Res. 23:389-396. DOI: 10.1007/s11248-013-9765-9.

Yu N, Christiaens O, Liu J, Niu J, Cappelle K, Caccia S, Huvenne H, Smagghe G. 2012. Delivery of dsRNA for RNAi in insects: an overview and future directions. Insect Sci. 20:4-14. DOI: 
662

Yu R, Xu X, Liang Y, Tian H, Pan Z, Jin S, Wang N, Zhang W 2014. The insect ecdysone receptor is a good potential target for RNAi-based pest control. Int J Biol Sci 10:1171-1180. DOI: 10.7150/ijbs.9598.

Zamore PD, Tuschl T, Sharp PA, Bartel DP. 2000. RNAi: double-stranded RNA directs the ATP-dependent cleavage of mRNA at 21 to 23 nucleotide intervals. Cell 101:25-33. DOI:10.1016/S00928674(00)80620-0.

Zha W, Peng X, Chen R, Du B, Zhu L, He G. 2011. Knockdown of midgut genes by dsRNA-transgenic plant-mediated RNA interference in the hemipteran insect Nilaparvata lugens. PLoS ONE 6:e20504. DOI: 10.1371/journal.pone.0020504.

Zhang H, Li HC, Miao XX. 2012. Feasibility, limitation and possible solutions of RNAi-based technology for insect pest control. Insect Sci. 20:15-30. DOI: 10.1111/j.1744-7917.2012.01513.x.

Zhang M, Zhou Y, Jones HD, Gao Q, Wang D, Ma Y. 2013. Identifying potential RNAi targets in grain aphid (Sitobion aveane F.) based on transcriptome profiling of its alimentary canal after feeding on wheat plants. BMC Genomics 14: 560. DOI: 10.1186/1471-2164-14-560.

Zhao Y, Yang G, Wang-Pruski G, You M. 2008. Phyllotreta striolata (Coleoptera: Chrysomelidae): arginine kinase cloning and RNAi-based pest control. Eur. J. Entomol.105:815-822. DOI: 10.14411/eje.2008.108.

Zhu JQ, Liu S, Ma Y, Zhang JQ, Qi HS, Wei ZJ, Yao Q, Zhang WQ, Li S. 2012. Improvement of pest resistance in transgenic tobacco plants expressing dsRNA of an insect-associated gene EcR. PLoS ONE 7: e38572. DOI: 10.1371/journal.pone.0038572.. 
683 Figure legends

684 Figure 1. Trajectory of Cy3-labeled dsRNA molecules through the tomato leaflets to the larval intestinal 685 track. (A). Confocal images of tomato leaflets exposed (b,d) or not (control) (a,c) to dsRNA from the $686 \quad$ V-ATPase gene fragment labeled with Cy3 (seen as red dye) by in vitro transcription, taken at $6 \mathrm{~h}$ (bar $687=250 \mu \mathrm{m})(\mathrm{a}, \mathrm{b})$ or $24 \mathrm{~h}(\mathrm{bar}=1 \mathrm{~mm})(\mathrm{c}, \mathrm{d})$ after treatment. Chlorophyll is seen as green fluorescence. 688 (B). Confocal images of first instar T. absoluta larvae fed on tomato leaflets exposed (larva on the right 689 hand side) or not (control - larva on the left hand side) to dsRNA from the V-ATPase gene fragment 690 labelled with Cy3 by in vitro transcription, taken $24 \mathrm{~h}$ after treatment (bar in $\mathrm{d}=250 \mu \mathrm{m}$ and applies to 691 other panels). Larval images were taken with bright light (a), 488 (b), 555 (c) channels and images a, b 692 and c were merged in $\mathrm{d}$.

693

696
Figure 2. Effect of the dsRNA uptake and PITIGS delivery methods on the relative expression of target genes in T. absoluta larvae. Relative expression of the target genes $V$-ATPase and $A K$ in T. absoluta larvae fed on tomato leaflets that absorbed a dsRNA solution (25 $\left.\mu \mathrm{g} \mathrm{mL} \mathrm{L}^{-1}\right)(\mathrm{A})$ and tomato leaflets that were infiltrated with Agrobacterium cells containing constructs that transcribed inverted repeats of the target gene fragments V-ATPase and $A K(\mathrm{~B})$. The larvae in A and B were sampled $24 \mathrm{~h}, 48 \mathrm{~h}$ and $72 \mathrm{~h}$ after the initiation of feeding. Gene expression was normalized to positive controls that were exposed to GFP dsRNA ( $n=3)$. The Rpl 5 gene was used as a reference gene $(n=3)$. The columns represent the mean \pm SE. $* P<0.05$ and ${ }^{* *} P<0.01$ (Student's $t$-test).

Figure 3. Effect of RNAi on larval mortality. The mortality of T. absoluta larvae was assessed after feeding on tomato leaves treated with dsRNA from V-ATPase, AK or GFP control for various intervals ( $n=10)$. Tomato leaflets were provided with $1 \mu$ g of each dsRNA (V-ATPase or AK, plus GFP control) per leaflet per day for 10 days (total of $10 \mu \mathrm{g}$ ). The columns represent the mean $\pm \mathrm{SE}$. 
705 Figure 4. Effect of RNAi on leaf damage caused by larval herbivory. Tomato leaflets that absorbed 706 increasing amounts (500, 1000 or 5000 ng) of GFP (a, b), V-ATPase (c, d) and AK (e, f) dsRNA were 707 exposed to herbivory by T. absoluta larvae for 11 days. Two replications (column 1 and 2) are shown 708 for each treatment.

Figure 5. RNAi transgenic plants. (A). Transgenic ‘Micro-Tom’ tomato leaflets after one (a-e) and seven days (f-j) of herbivory by T. absoluta larvae. Pupae (k-o) obtained from the respective treatments. (B) Average pupal weight obtained from larvae fed on the various transgenic leaflets. The columns represent the mean \pm SEM $(n=6-10)$.

\section{Supplementary Figures}

Figure S1. Multiple alignment of translated cloned sequences from Tuta absoluta and homologs from other insect species. For Vacuolar ATPase subunit-A: Aedes aegypti (XP_001659520.1), Drosophila melanogaster (NP_652004.2), Tribolium castaneum (XP_976188.1), Manduca sexta (P31400.1), Bombyx mori (NP_001091829.1) and Tuta absoluta (KM591219). Arginine kinase: Spodoptera litura (ADW94627.1), Helicoverpa armigera (ADD22718.1), Bombyx mori (NP_001037402.1), Tribolium castaneum (EFA11419.1), Homalodisca vitripennis (AAT01074.1), Drosophila melanogaster (AAA68172.1) and Tuta absoluta (KM591220). Red letters refer to perfect consensus among the seven sequences; blue partial consensus; and black no consensus.

Figure S2. High magnification of the trajectory of Cy3-labeled dsRNA molecules through tomato leaflets. Detail of various regions of treated leaves indicating the dsRNA distribution over leaf areas (bar = 200 $\mu \mathrm{m})$.

Figure S3. PITIGS proof of concept; Agroinfiltration experiments with Agrobacterium expressing eGFP or eGFP plus GFPi. (A) Expression of eGFP in a tomato leaf infiltrated with Agrobacterium suspension containing a plasmid with eGFP. (B) Infiltration of a tomato leaf with two Agrobacterium 
728 lines expressing eGFP together with a construct expressing GFPi. Note the decrease in GFP

729 expression. (C) Tomato leaf tissue distant from the area infiltrated with Agrobacterium suspension

730 containing a plasmid with eGFP. All images were obtained by confocal fluorescence microscopy. Bar

$731=100 \mu \mathrm{m}$ in all panels.

732 Figure S4. Effect of RNAi on larval development. Tuta absoluta individuals after feeding on tomato

733 leaflets for 11 days and absorbing 500 ng of dsRNA of the GFP control (a) and the target genes $V$ -

734 ATPase (b) and $A K(\mathrm{c})$. The total number of individuals that reached the pupal stage after feeding on

735 the GFP control is shown in d and the target genes $V$-ATPase and $A K$ in the larval stage are shown in e 736 and f, respectively.

Figure S5. Detection by RT-PCR of expressed sequences (cDNA, siRNA and microRNA) from various transgenic events. (A) Detection of cDNA amplification products (RT-PCR) from various transgenic 'Micro-Tom' events and the non-transformed control (WT) using primers specific for insect V-ATPase (top panel; 139 bp) or AK (bottom panel; 190 bp) and tomato ubiquitin (UBI, 108 bp). (B) Detection of amplification products for potential siRNA derived from target genes ( $V$-ATPase or AK, both $60 \mathrm{bp}$ ), plus the microRNA156 (MIR156; $60 \mathrm{bp)} \mathrm{control.} \mathrm{The} \mathrm{products} \mathrm{were} \mathrm{obtained} \mathrm{by} \mathrm{stem} \mathrm{loop} \mathrm{pulsed} \mathrm{RT-}$ PCR and analysed by electrophoresis in 3\% agarose gels. Numbers represent events (first number) and plants within events (second number).

\section{Supplementary tables}

Table S1. Degenerated primers used to amplify and clone respective candidate target genes for RNAi and the expected amplicon size for each reaction. Numbers refer to the primer order used in the amplification reactions. 
749 Table S2. Primers used to amplify target gene fragments with Gateway recombination borders attL1 and $750 \quad$ attL2 (underlined) and the expected amplicon size.

751 Table S3. Summary of three transformation experiments that used constructs containing repetitive and 752 inverted gene fragments.

753 Table S4. Specific primers designed for transcriptional analysis of target genes for silencing and the $754 \quad$ expected amplicon size.

755 Table S5. Gene-specific and universal primer sequences used to detect the predicted small interfering 756 RNAs (siRNA) derived from the target genes V-ATPase (siRNA AATACATGCGCGCTCTAGATGAC)

757 and $A K$ (siRNA AAGTATCGTCCACACTGTCTGGC) and the control microRNA156 758 (UGACAGAAGAGAGUGAGCAC) in transgenic plants. 


\section{Figure 1}

Trajectory of Cy3-labeled dsRNA molecules through the tomato leaflets up to the larvae intestinal track.

(A) Confocal images of tomato leaflets exposed $(b, d)$ or not (control) $(a, c)$ to dsRNA from $V$ ATPase gene fragment labeled with Сy3 (seen as red dye) by in vitro transcription, taken at 6 $\mathrm{h}(\mathrm{bar}=250 \mu \mathrm{m})(\mathrm{a}, \mathrm{b})$ or $24 \mathrm{~h}(\mathrm{bar}=1 \mathrm{~mm})(\mathrm{c}, \mathrm{d})$ after treatments were imposed. Chlorophyll is shown as green fluorescence. (B) Confocal images of $1^{\text {st }}$ instar Tuta absoluta larva fed on tomato leaflets exposed (larva on the right hand side) or not (control - larva on the left hand side) to dsRNA from V-ATPase gene fragment labeled with Cy3 by in vitro transcription, taken $24 \mathrm{~h}$ after treatments were imposed (bar $=250 \mu \mathrm{m}$ ). Larvae images were taken with bright light (a), 488 (b), 555 (c) channels and images a, b and c were merged in d.

A

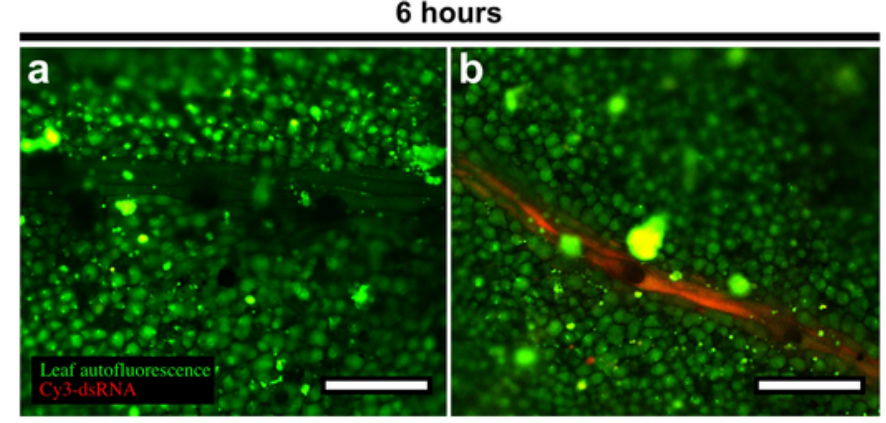

B

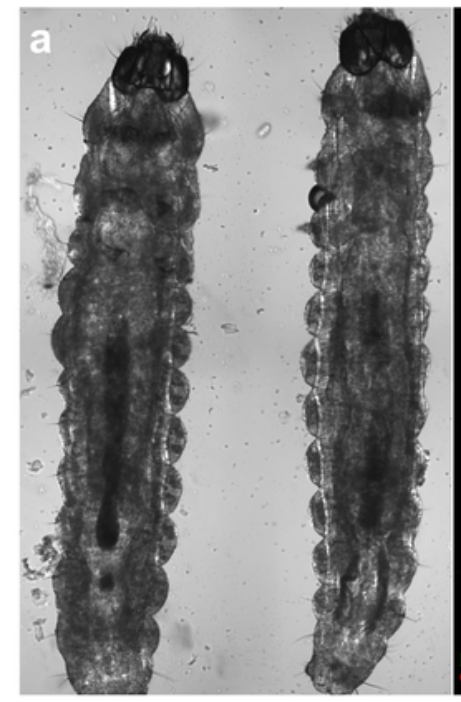

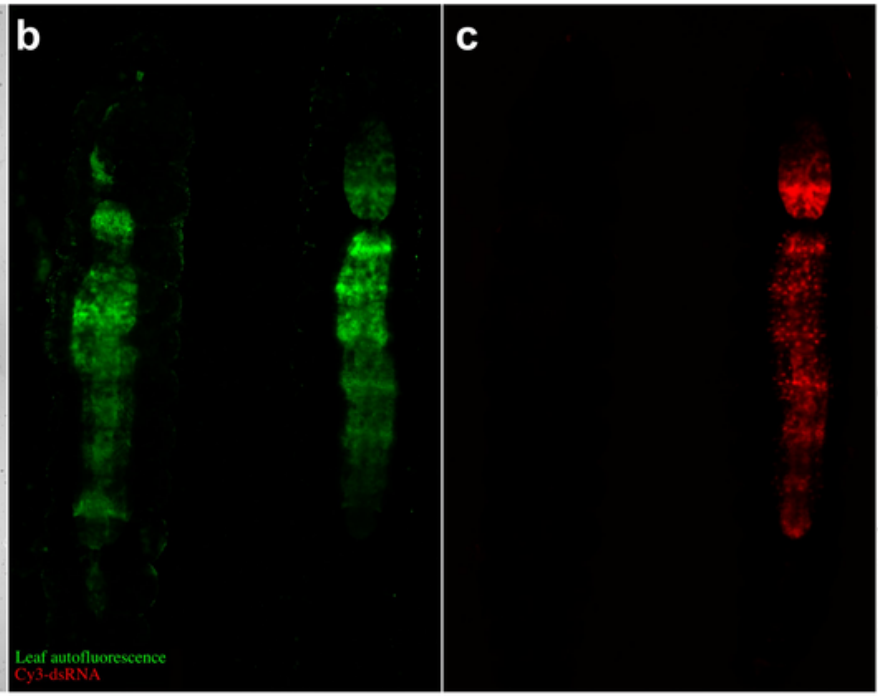

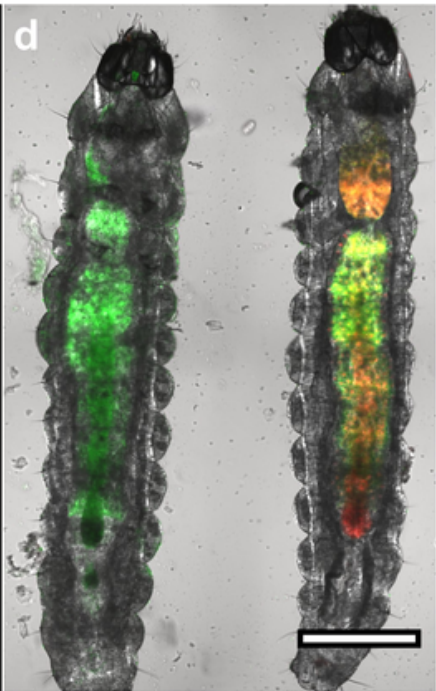


Figure 2 (on next page)

Effect of the dsRNA uptake delivery method on the relative expression of target genes in $T$. absoluta larvae.

Relative expression of target genes V-ATPase and AK in larvae of $T$. absoluta fed on tomato leaflets that absorbed dsRNA solution ( $25 \mu \mathrm{g} \mathrm{mL} \mathrm{L}^{-1}$ ), sampled at 24,48 and $72 \mathrm{~h}$ after initiation of treatments normalized to positive controls that were exposed to GFP dsRNA $(n=3)$. The $R p l 5$ gene was used as gene reference $(n=3)$. The asterisk indicates significant differences (t-test; "*” at $P<0.05$; “**” at $P<0.01$ ). 
A

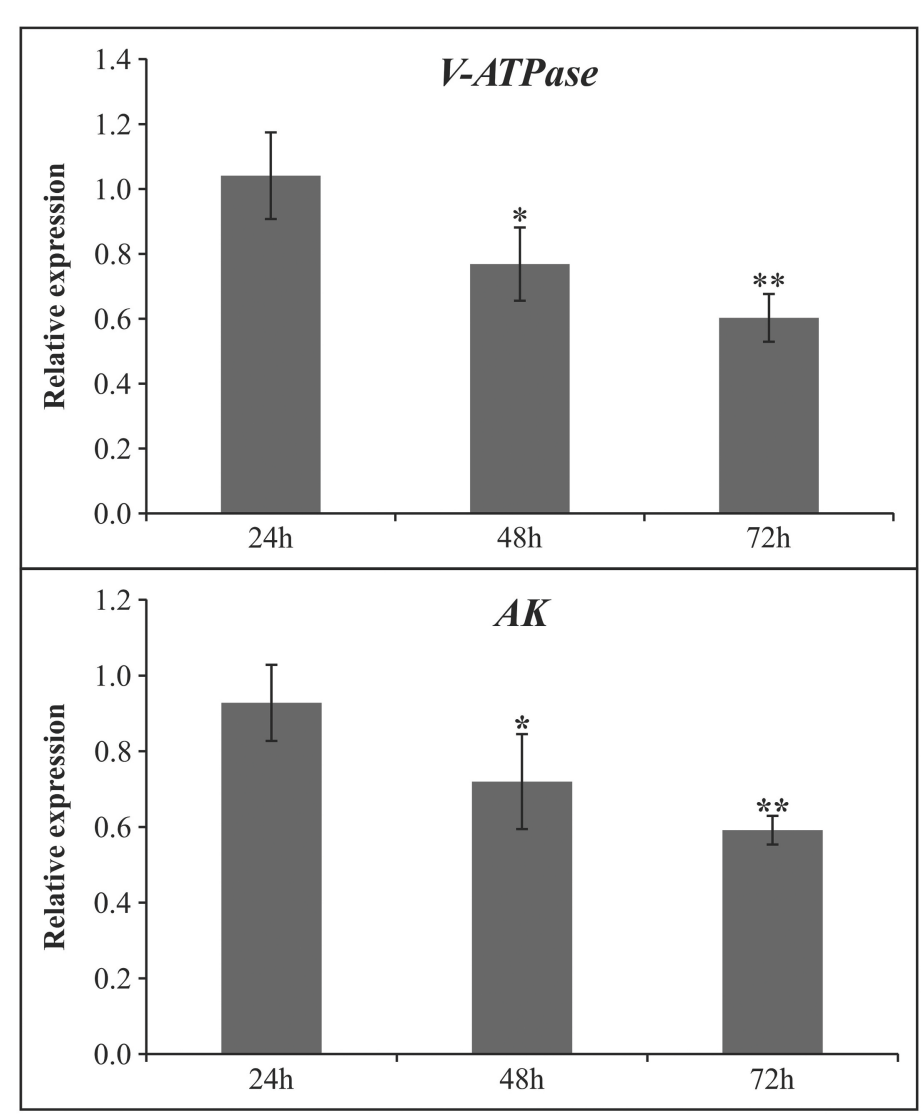

B

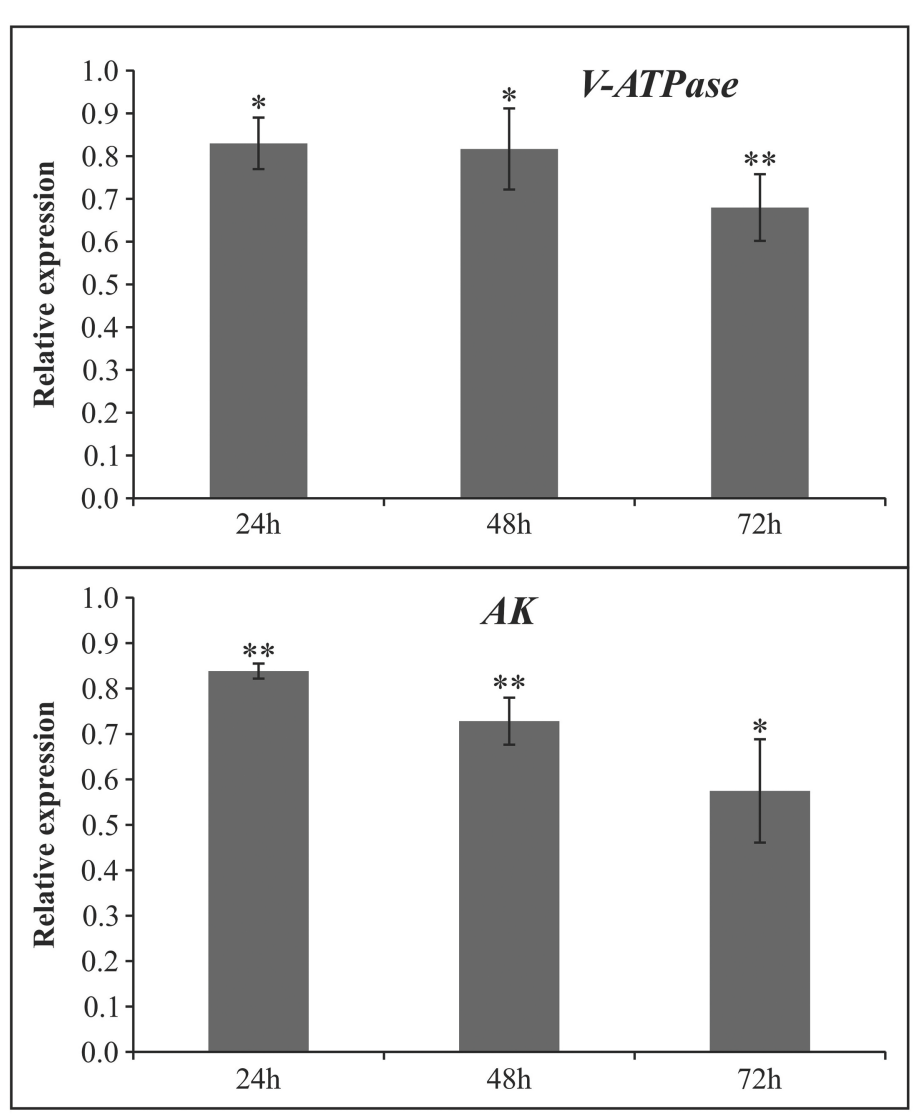




\section{Figure 3 (on next page)}

RNAi effects on larval mortality.

Mortality of Tuta absoluta larvae $(n=10)$ after feeding on tomato leaf treated with dsRNA from V-ATPase, AK or GFP control for 24 days. Tomato leaflets were provided with one $\mu \mathrm{g}$ of each dsRNA (V-ATPase or AK, plus GFP control) a day per leaflet for 10 days in a total $10 \mu \mathrm{g}$. 


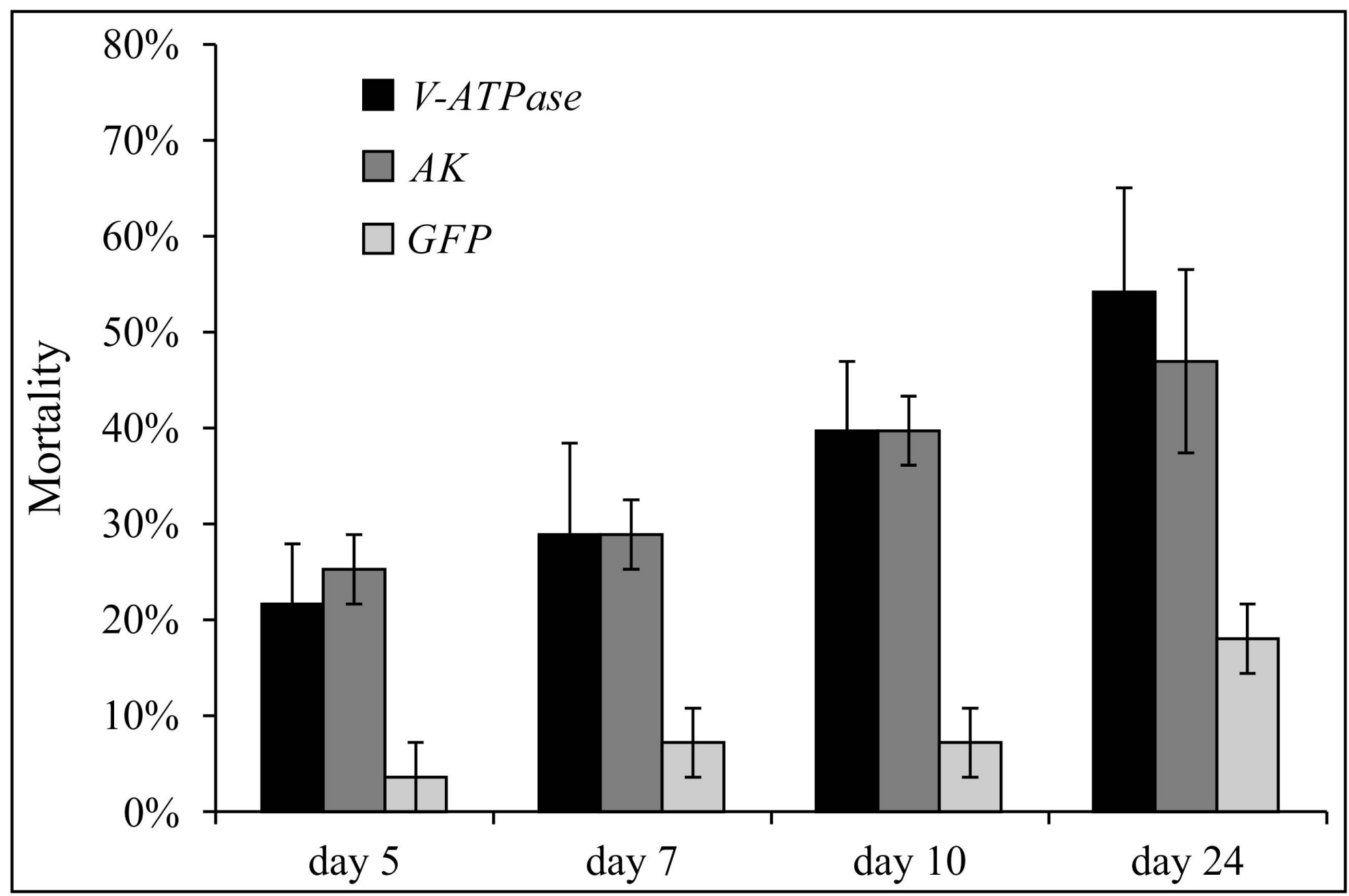


Figure 4 (on next page)

RNAi effects on leaf damage caused by larval herbivory.

Tomato leaflets that absorbed increasing amounts of dsRNA (500, 1000 or $5000 \mathrm{ng}$ ) of GFP $(a, b), V$-ATPase $(c, d)$ and $A K(e, f)$, submitted to $T$. absoluta larvae hebivory for 11 days. 
PeerJ

\section{Day 11}

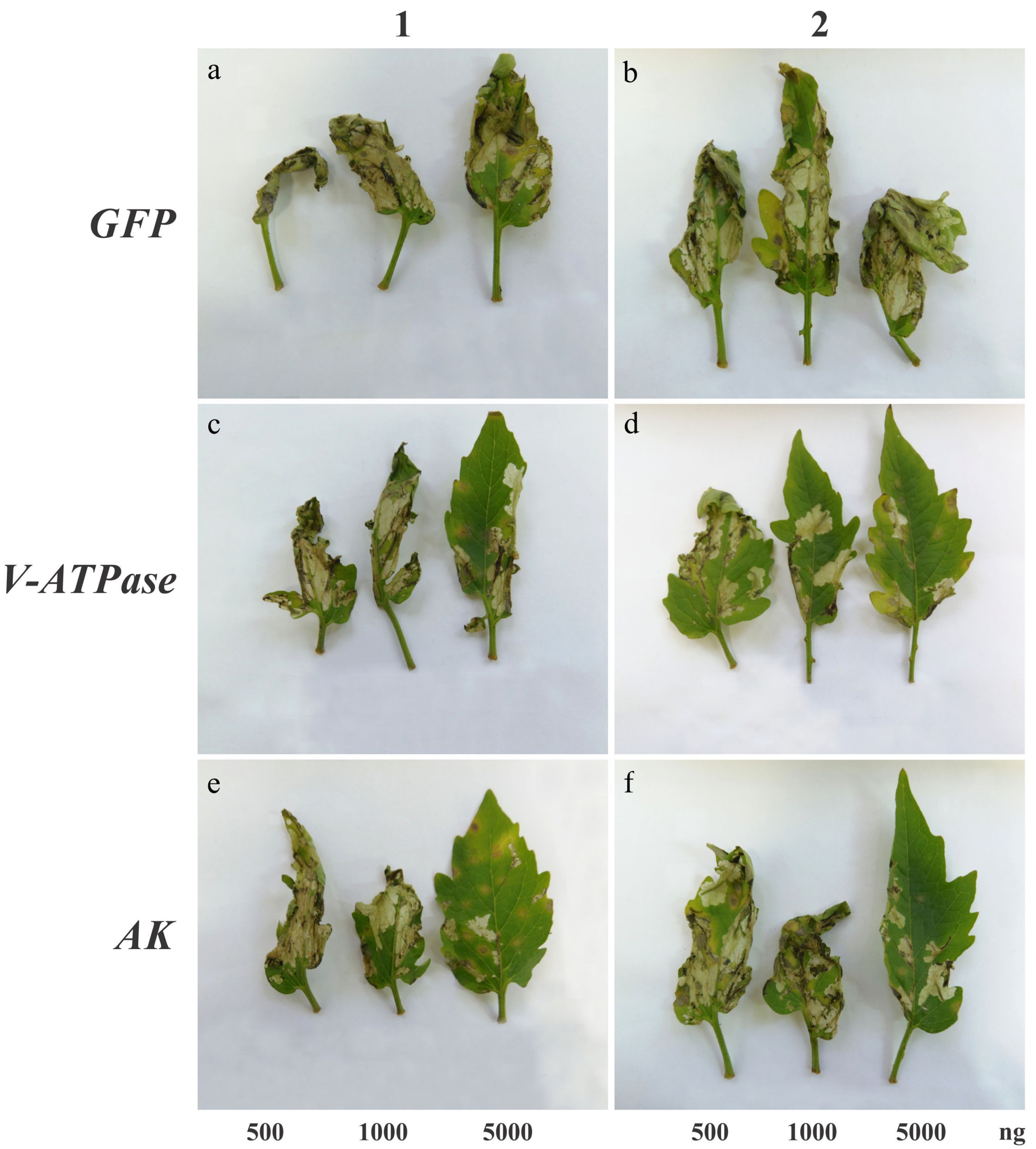


Figure 5 (on next page)

RNAi transgenic plants.

(A). Transgenic 'Micro-tom' tomato leaflet at one (a-e) and seven days after (f-j) T. absoluta larva herbivory. Pupae (k-0) obtained from the respective treatments. (B) Average pupae weight obtained from larvae fed on the various transgenic events, with standard error $(n=6$ 10). 
A

PeerJ

ATPase 1.1

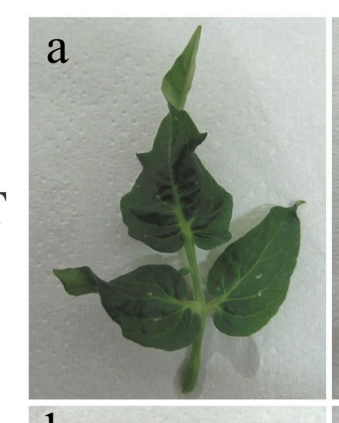

DAY 7

WT
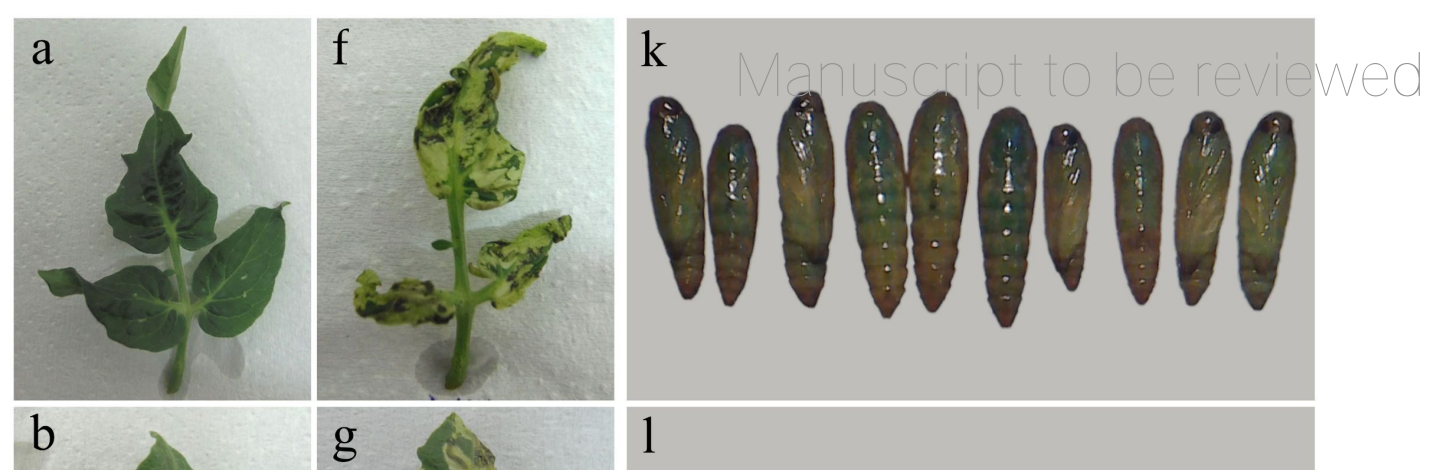

ATPase 7
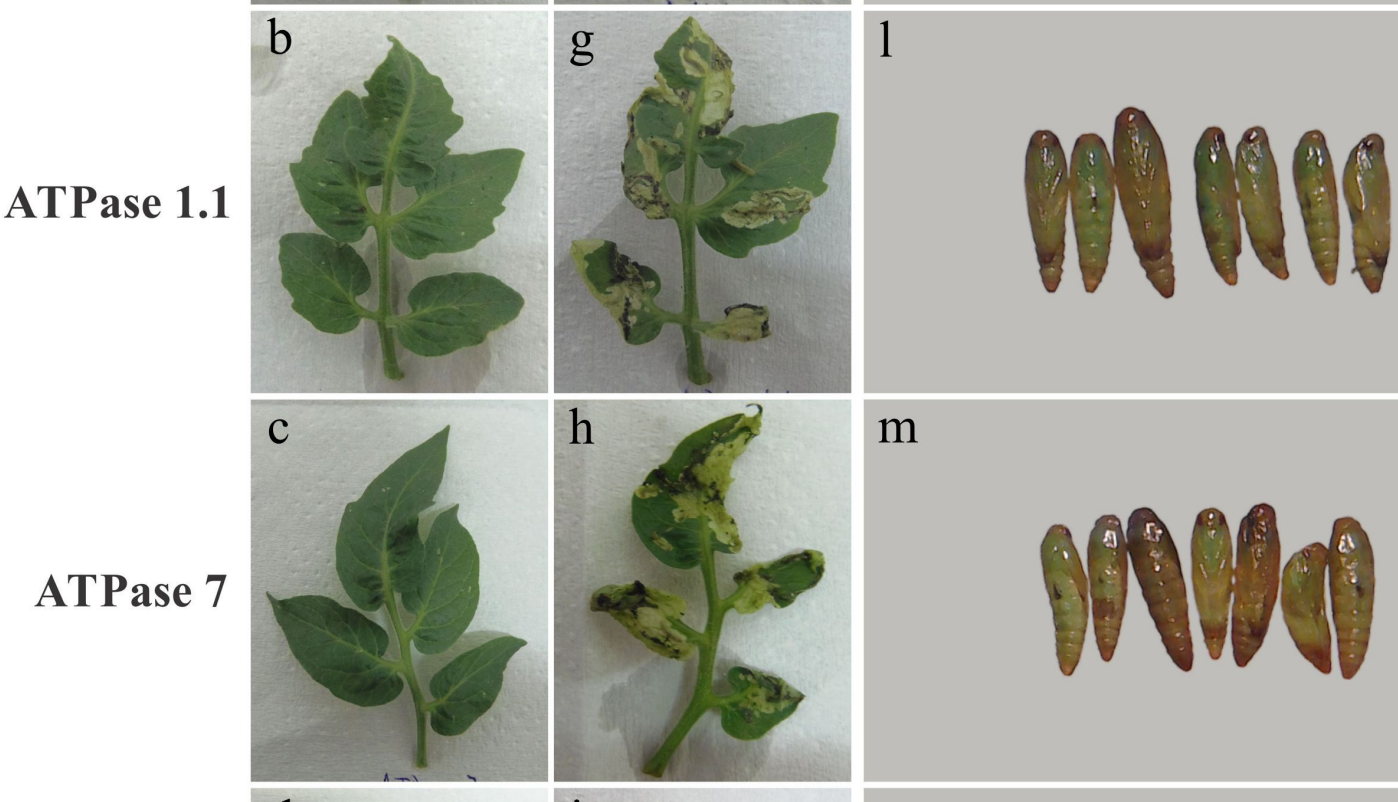

$\mathrm{m}$

ATPase 9
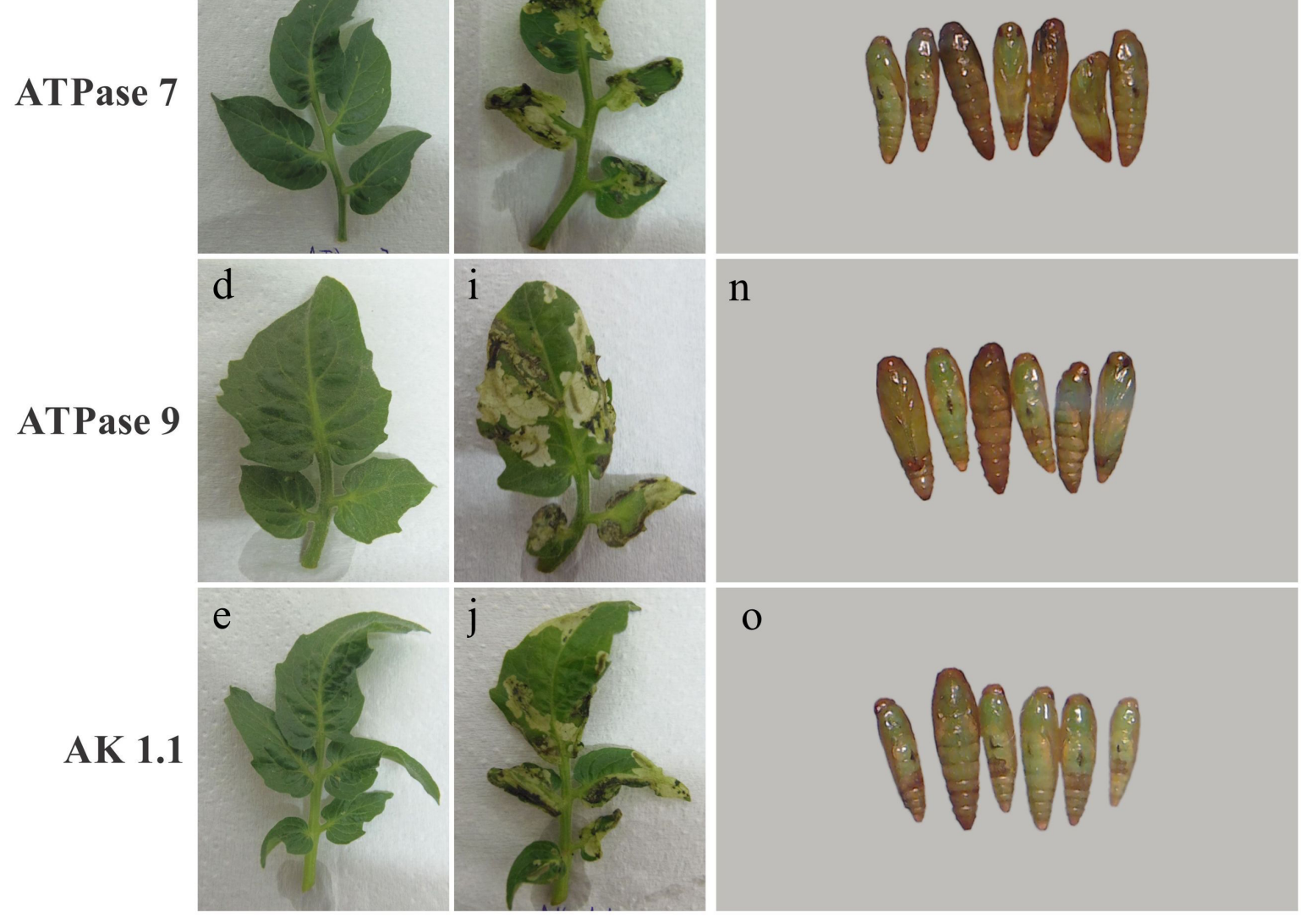

n

B

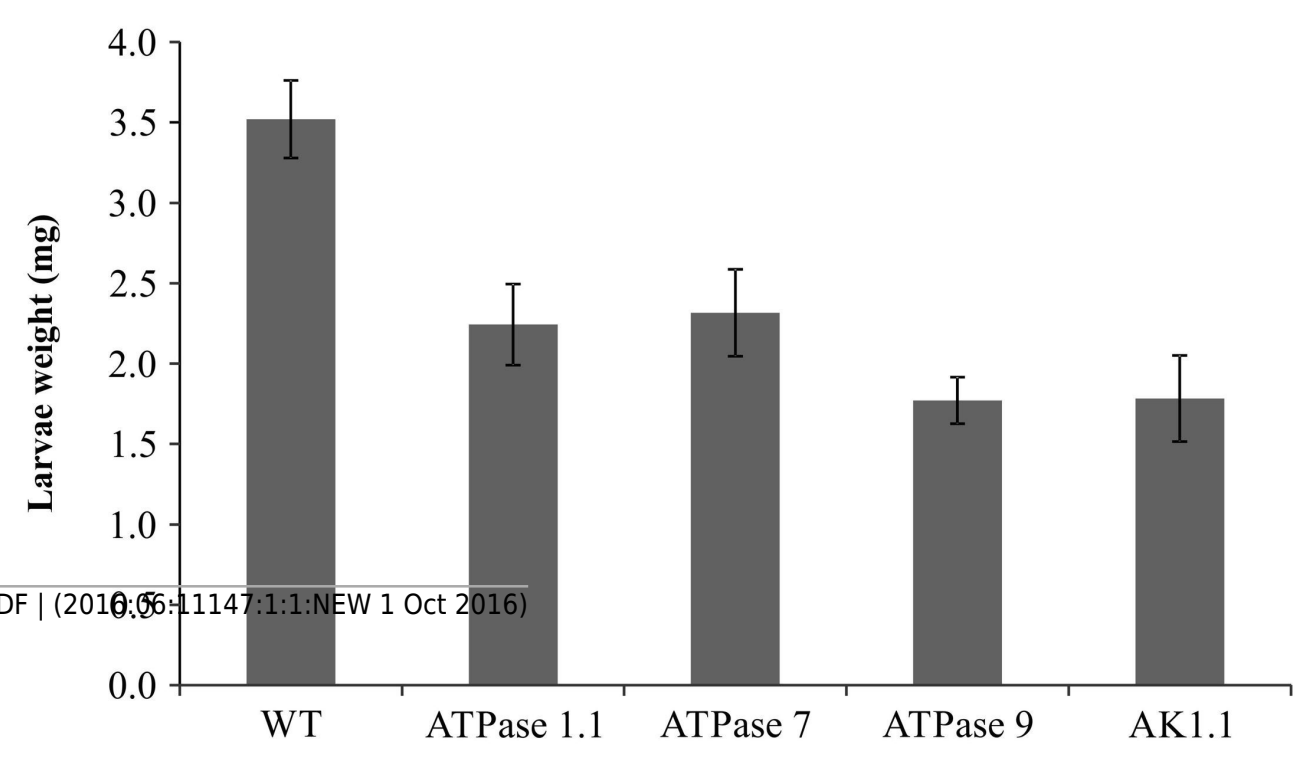

Peer) reviewing PDF | (2010:56:-1147:1:1:NEW 1 Oct 2016)
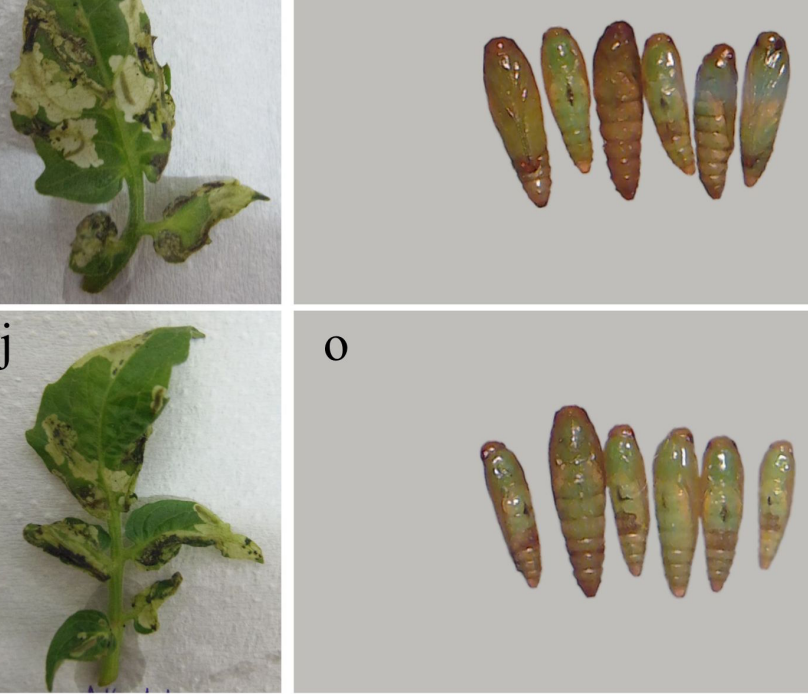

o

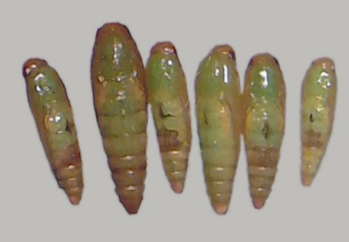

